\title{
568 - A HISTORICAL DATE AND ITS ARCHAEOLOGICAL CONSEQUENCES*
}

\author{
ISTVÁN KONCZ
}

\author{
Institute of Archaeological Sciences \\ Eötvös Loránd Univerity, Faculty of Humanities \\ Múzeum krt. 6-8, H-1088 Budapest, Hungary \\ fredgar22@gmail.com
}

\begin{abstract}
Written sources reveal that a political power shift and an excessive change of population took place in Pannonia in 568. Archaeological data suggest, however, coexsistence between communities different origins despite the community level realignment of society. The author would like to highlight some neglected examples that could provide details of vital importance for the topic and connect it to well known sites, all too often having complex and unclear interpretations. Continuity is analysed through the last phase of Langobard Period cemeteries, presuming that they were still in use during the last third of the $6^{\text {th }}$ century, and through the early phase of Avar Period cemeteries, as their connection networks are the same: an intensive interaction with the western Merovingian and the Mediterranean world. This connection is evident in certain arte fact types (belts, weapons, brooches) and in attireas a whole as well.

Keywords: continuity, early Avar Period, Langobards, migration, Pannonia, early Medieval archaeology

„Then the Langobards, having left Pannonia, hastened to take possession of Italy with their wives and children and all their goods. They dwelt in Pannonia forty-two years. They came out of it in the month of April in the first indiction on the day after holy Easter, whose festival that year, according to the method of calculation, fell upon the calends (the first) of April, when five hundred and sixty-eight years had already elapsed from the incarnation of our Lord." 1
\end{abstract}

\section{INTRODUCTION}

Paulus Diaconus's often quoted chapter fundamentally determined Langobard research and thus the archaeo$\operatorname{logy}$ of $6^{\text {th }}$ century Pannonia from the very beginning. The question, whether there had been any Langobard continuity after 568 in Pannonia was raised in 1933. That year the cemetery of Várpalota was found, which included graves from both the Langobard and the Avar Periods side by side. As an outcome of the heated debate between Joachim Werner, István Bóna and Max Martin the question was neglected. István Bóna dated the abandonment of Langobard Period cemeteries to 568, which became the widely accepted dividing line between the Langobard and the Avar Periods not by historians, but archaeologists as well. This date froze as an unbreakable terminus ante quem in Hungarian research. ${ }^{2}$

In recent years international research made the post-568 dating of specific artefacts such as the belt mount from grave 30 in Szentendre-Pannoniatelep ${ }^{3}$ or from grave 122 in Bratislava-Rusovce ${ }^{4}$ probable, thereby presum-

* The research was granted by the National Research, Development and Innovation Office (NKFIH), decision number: OTKA NN 113157.

${ }^{1}$ Paulus Diaconus: Historia Langobardorum II./7. Translated by William Dudley Foulke.

${ }^{2}$ BÓNA 1956, 239-242; BÓNA 1971, 51-52; BÓNA 1993, 111-120. As in Langobard research, the date 568 appeared as a significant dividing line in the research of Gepids as well. Its revision has only started in recent years: KIss P. 2011, 14-15. Outlined in: DoBos 2013, 98-101.
${ }^{3}$ Von FREEDEN 2000, 111-112.

${ }^{4}$ Dated to after 568 unequivocally: SCHMIDTOVÁ-RUTTKAY 2007, 353-354. A more cautious dating: SCHMIDTOVÁ-RUTTKAY 2008, 392-393. The interpretation of the belt mount is further complicated by its second animal style decoration. It was analyzed in detail by Orsolya Heinrich-Tamáska. HeInRICH-TAMÁsKa 2005, 281. The ${ }^{14} \mathrm{C}$ analysis of the grave was inconclusive. SCHMIDTOVÁ-RUTTKAY 2008, 393-394, and http: //antiquity.ac.uk/projgall/sefcakova/ (01.05.2015) 
ing the continuity of Langobard Period population groups into the early Avar Period. ${ }^{5}$ A research boom during the last two decades, mainly new, modern excavations, and the publication of the older materials make renegotiating the question not only possible but necessary.

In this paper I would like to review artefacts from Langobard Period cemeteries which could be dated to after 568, demonstrating with the help of some selected early Avar cemeteries that the network of connections among the population in Pannonia did not change significantly in 568 .

\section{1. The Várpalota-debate}

The cemetery of Várpalota-Unio homokbánya had been excavated in 1933 by Gyula Rhé, but it was published posthumously by I. Bóna in $1956 .{ }^{6}$ The combined appearance of Langobard and Avar Period graves makes this cemetery of 36 graves $^{7}$ particularly interesting. Several of the 27 Langobard Period graves were richly furnished (a man with a whole set of weapons from grave 11, females in four-brooch costumes (Vierfibeltracht) from graves 1, 5 and 17). Based on the grave goods and horizontal stratigraphy, J. Werner was able to distinguish three chronological phases. He dated graves 5 and 25 as founding burials of the cemetery between 530 and $550 .{ }^{8}$ The second phase is dated to 550-568 and includes graves 1, 17 and 19. Based on their positions graves 13 and 34 were dated to after 568 . Grave 13 lay parallel, tightly next to Avar Period grave 20 and its orientation is the same. Grave 34 forms a family group together with other female burials - such as grave 9, 13 and 20 - and Avar Period male grave 12. ${ }^{9}$ Beside the stratigraphic position of the Langobard and Avar Period burials J. Werner used the undisturbed nature of the graves as an argument. ${ }^{10} \mathrm{~J}$. Werner took it granted that the cemetery founded in the Langobard Period was used during the early Avar Period, and that continuity existed not only in the location, but between the populations as well. ${ }^{11}$

I. Bóna also dated the foundation of the cemetery to 530, but the abandonment to 568 and denied the connection between the Langobard and Avar Period graves. ${ }^{12}$ In her review of J. Werner's work Ilona Kovrig did not see evidence for the synchronity of the latest Langobard and the earliest Avar Period graves, her most important argument being the lack of combination between the elements from two different material cultures, ${ }^{13}$ and the erroneous stylistic dating of grave 13, which according to her should be dated to the earliest phase of the cemetery. ${ }^{14}$ I. Bóna explained the presence of Avar Period graves at the Langobard Period burial site with the geographical importance of the location, and emphasized only the continuity of the location, but denied the continuity of the population. ${ }^{15}$

The last overview of the problem was published by M. Martin: he approached the question from the viewpoint of graves - 9, 12, 20, 24, 27, 28 - safely dated to the Avar Period. ${ }^{16}$ The earliest Avar Period graves could only be dated to the turn of the $6^{\text {th }}$ and $7^{\text {th }}$ century, therefore they can not be seen as direct continuations to the Langobard Period burials. ${ }^{17}$ The two periods differ both in terms of grave goods and burial rite. ${ }^{18}$ He deemed J. Werner's explanation, that graves without grave goods belonged to Langobard slaves subjugated by the Avars, unrealistic. Max

f 5 Problem raised by VIDA 2008, 348.

${ }^{6}$ BÓNA 1956, 185-191.

${ }^{7}$ Thirty-five graves were found during the excavation and one (grave A) was observed by Jenö Faller. Grave 4 is a double burial. BóNA 1956, 187-191. J. Werner mentions a new section of the cemetery with 37 graves excavated in 1943/44. WERNER 1962, 23. In 1963, I. Bóna verified that the whole cemetery had been excavated, and clarified that the afore-mentioned part of the cemetery had been included by a misunderstanding. It is a different cemetery in a different part of Várpalota: BóNA 1963, 119.

${ }^{8}$ As J. Werner dated the founding of the cemetery to 530, he also sided with the theory of the Langobard settlement to Pannonia in 526/27, against 546: WERNER 1962, 45-46. The chronology is based on the detailed analysis of the brooches and the horizontal stratigraphy. WERNER 1962, 37-44.

${ }^{9}$ WERNER 1962, 30.

${ }^{10}$ WeRnER 1962, 31. I. Bóna explained this phenomenon with the abandonment of the cemetery around 550, meaning that when the Langobards left Pannonia in 568 they didn't rob the burials: BóNA 1993, 160. I. Bóna disproved his theory with the detailed analysis of the brooches which showed that the cemetery had been used even after 550. BÓNA 1993, 136-137.

${ }^{11}$ WERNER 1962, 47-48.

12 BÓNA 1956, 216-217 and BÓNA 2000, 152-154.

241.

${ }^{13}$ This argument was raised earlier by I. Bóna: BóNA 1956,

${ }^{14}$ KovRIG 1964, 146. Although I. Kovrig accepts I. Bóna’s observations in the case of Várpalota, she reckons with a sedentary population post-dating the Langobard migration to Italy.

${ }^{15}$ BÓNA 1956, 241 and BónA 2000, 152.

${ }^{16}$ I. Bóna dated grave 15 to the Avar Period, but after his revision M. Martin dated it to the Langobard Period: MARTIN 1976, 195 and 199; BÓNA 1956, 191.

${ }^{17}$ MARTin 1976, 199.

${ }^{18}$ MARTIN 1976, 196. 
Martin interpreted the difference in grave goods between the graves as a sign of a more complex, differentiated social organisation within the funerary community. ${ }^{19}$ According to M. Martin, in addition to I. Bóna and I. Kovrig, the co-habitation between Langobards and Avars could not be proven.

\section{2. The historical approach}

Considering the date 568 the cornerstone in the $6^{\text {th }}$ century history of Pannonia and the previously quoted chapter from Paulus Diaconus have been widely debated among historians as well. Within the framework of this paper it is impossible to summarize relevant historical research in detail. I would only like to point out, that among historians the idea occurred long ago. Moreover it is generally accepted that the chapter by Paulus Diaconus neither means the sudden evacuation of Pannonia, as I. Bóna thought,$^{20}$ nor does it rule out the possibility of population continuity in the early Avar Period.

The tropic nature of mass migrations or migrations of entire peoples was pointed out by Jörg Jarnut, who in the case of the Langobards assumed that only a significant part of the population moved to Italy. ${ }^{21}$ Walter Pohl writes about the population groups left behind having fallen under Avar rule. ${ }^{22}$ Although in the interpretation of the Langobard migration W. Pohl and Michael Borgolte represent different theories, ${ }^{23}$ they take a common stand on the issue of population continuity. W. Pohl highlights the role of King Alboin, who as a charismatic leader and main organizer commanded the resettlement in one big wave. ${ }^{24}$ Unlike W. Pohl, M. Borgolte emphasized several, small and long lasting (even 2-3 decades) waves of migration lead by the dukes (dux) based on the period of "interregnum" in Italy, although he did not question the importance of the King. ${ }^{25}$

The proliferation of demographic and sociological migration theories ${ }^{26}$ compelled archaeologists to reevaluate these processes. ${ }^{27}$ Two attributes from Stefan Burmeister's criteria developed for early medieval migrations are highly important from the viewpoint of this paper: a migration process is always accompanied by return migrations and migrations are selective with only a slice of the population participating. ${ }^{28}$ The archaeological traces of these two attributes are indistinguishable, as they appear as remaining parts of the moving population. Chris Wickham pointed out the logistic and organizational difficulties - discussed by both W. Pohl and M. Borgolta regarding the Langobards - of moving the whole populations. He sees it possible only in very specific scenarios, but not in the case of early medieval migrations. ${ }^{29}$

\section{METHOD}

There are multiple aspects of population continuity: ${ }^{30}$

1. biological continuity ${ }^{31}$

2. continuity of structures

3. continuity of culture/identity

\footnotetext{
${ }^{19}$ MARTin 1976, 197-198.

${ }^{20}$ BÓNA 1956, 241-242.

21 "die große Mehrzahl der Langobarden zum Abzug aus Pannonien veranlaßten”: JARNUT 1993, 179.

${ }^{22}$ PoHL 1988, 57.

${ }^{23}$ They are of the same opinion concerning the reasons of Langobard migration. They both think that the allurement of Italy and the fortunate political situation after the end of the Byzantine-Gothic wars (pull factors) were the main driving forces behind the migration and not the threat by Avars (push factor).

${ }^{24}$ POHL 2007, 225-227.

${ }^{25}$ In the theory put forward by M. Borgolte an important role is played by the population groups left behind. Presumably they were not immediately within the Avar state and society, but existed as communities capable of making autonomous decisions. They had their
}

own ruling elites that could orchestrate new waves of migrations: Borgolte 2013, 307-310.

${ }^{26}$ Primarily the push and pull factors listed by Everett S. Lee: LEE 1966, 49-54.

${ }^{27}$ Roland Prien summarized the work of J. Jarnut and Volker Bierbrauer concerning the Langobard migration and although he gave detailed overview of the new viewpoints, those don't influence his own interpretation: PRIEN 2005, 103-118.

${ }^{28}$ BuRMEISTER 1998, 36

${ }^{29}$ WickHAм 2005, 12.

${ }^{30}$ Based on the idea by: KoBYLínsKi 1994, 304-305.

31 Although beyond the reach of archaeology, the appearence of various scientific methods - such as stable isotope and DNA analyses - has made testing such ideas possible. 
The continuity of structures means the survival of life-determining systems such as settlement structures, spatial organisation, social hierarchy and the place of the population within its network of connections. The continuity of culture or identity is both the continuity of material culture and self-image, including ethnicity, religion and every other ideology that has the power to shape the population. The $2^{\text {nd }}$ and $3^{\text {rd }}$ points can not be sharply separated; they stand in a continuous, two-way connection. Certain aspects of the $2^{\text {nd }}$ and $3^{\text {rd }}$ points can be analysed archaeologically.

Various migration theories in archaeology have usually focused on the continuity of culture/identity which is - beyond typo-chronological observations - mostly on the basis of the "ethnic" interpretation of certain artefacts. The $6^{\text {th }}$ and $7^{\text {th }}$ century continuity of late Roman population was approached in the same way in Frankish territory and in the Keszthely culture. Late Roman populations were distinguished from the newcomers based on certain Mediterranean artefact types (earrings with basket-shaped pendants, stylus pins, and disc brooches), decoration elements (cross motif) and burial customs compatible with Christian ideology (burial assemblages containing very few or no grave goods). ${ }^{32}$ One of the definitive debates in Anglo-Saxon archaeology is the Anglo-Saxon migration and the survival of the autochthonous population. Beyond artefact types, settlement and house structures and space use have also been considered as arguments: sunken featured buildings were used both as evidence for (the building type itself and its continental origins) and against (length to width ratios, similar to those of late Roman buildings) autochthonous continuity. ${ }^{33}$

The review of the debate over ethnic interpretation of certain artefact types, dress or burial customs exceeds the goals of this paper. Recently, a complex analysis of economic, social and cultural processes taken over the simple ethnic interpretation of archaeological materials. ${ }^{34}$ Never-the-less this novel approach is based on typochronological observations as well. Because artefacts can no longer be used as pure ethnic markers, the analysis of population continuity should be placed on a new footing.

Regarding the continuity of population after 568 it is important to note that archaeological dating methods ${ }^{35}$ are unsuitable for certainly deciding whether an object (or burial assemblage) was buried before or after 568 (an even 567 versus 569 precision is hopeless). ${ }^{36}$ The typology of objects offers only a relative chronology, therefore it is suitable only for the analysis of long term processes and changes. Absolute dates are rare, non-existent or not sufficiently accurate. ${ }^{37}$ In order to decide whether there is continuity or not, using typo-chronology is inevitable despite its apparent limitations. In this case the main reason for this is the amalgamation of Langobard and Avar Period artefact types. Continuity can be analysed through the last phase of certain Langobard Period cemeteries, presuming that they were still in use during the last third of the $6^{\text {th }}$ century, and through the early phase of Avar Period cemeteries. This approach, however, is partially based on the previously discussed ethnic interpretations.

My methodological baseline has been that every individual has a unique connection network that is not imitable, and has its own origins. These are as specific to the individual as a fingerprint. Communities have their own connection networks as well, originating from the connections of its members and from the connections essential for the existence of the community. Such connections are not necessary created between individual actors, but between communities. Connections covering vital needs (such as salt or grain etc.) and products that are rare or hard to come by (for example garnet in the $5^{\text {th }}$ and $6^{\text {th }}$ centuries) by their nature can be built up similarly between different communities. However, most artefacts (jewellery, dress accessories etc.) studied by archaeologists are subject to individual choice or taste, which leads to the development of individual connections and these connections can be examined through the typological analysis of the archaeological material. In case of continuity this means that

${ }^{32}$ V Bierbrauer's Romanised culture-model: BIERBRAUER 1996, 111-113. In case of the Keszthely culture among others: BIERBRAUER 2004, 68-71 and VIDA 2011, 415.

${ }^{33}$ Halsall 2012, 29-31. Pro migration: Hamerow 2002, 48-51. Pro continuity: LuCY 2000.

${ }^{34}$ Possibilities of ethnic interpretation in detail: BRATHER 2004, FEHR 2010.

${ }^{35}$ The scarce number of burials from the first half of the $6^{\text {th }}$ century in Pannonia and the high rate of robbing of the graves (35$100 \%$ ) make the use of different statistical methods problematic, so even the relative chronology of this period in Pannonia is built with the help of detailed western Merovingian chronologies. It must be taken into account, that these chronologies are localized (Southern Germany, Lower Rhine region, Middle Danube region etc.) and thus regional differencies may occur.

36 The detailed critique of both archaeological and historical dating methods: STEUER 1977 and BÁLINT 1993, 200-214.

${ }^{37}$ As of today, not even scientific methods have been accurate enough for dating with such precision in this period. Some results of ${ }^{14} \mathrm{C}$ analysis from the $6^{\text {th }}$ century: STADLER et al. 2005 and BENEDIX 2015, 70-72. 
if a given region is evacuated, then there must be a drastic disruption in the network of connections in the region. Vital connections can be built up the same way as before, but as a whole the connection network changes according to the needs of the new population. Continuity, discontinuity and the way change is taking place in the network of connections in a given region is a source for the studying the continuity between populations.

\section{THE LATEST PHASE OF THE LANGOBARD PERIOD CEMETERIES}

\section{1. The cemetery of Szentendre-Pannoniatelep}

The dating of two belt mounts from the cemetery of Szentendre (from graves 30 and 34) has been debated over the last decade. These two finds do not fit within the historical framework of pre 568 dating, where 568 is used as an absolute terminus ante quem to every Langobard Period cemetery. ${ }^{38}$ The pressed sheet fragments from grave 81 were described by I. Bóna as parts of the footwear decoration, ${ }^{39}$ but their form and ornaments are unique in Langobard Period Pannonia. The detailed analysis of the cemetery and the afore-mentioned graves is yet to be carried out, because the report was only published in $2009 .{ }^{40}$ The study of graves 30 and 34 is made more difficult due to their heavily disturbed condition.

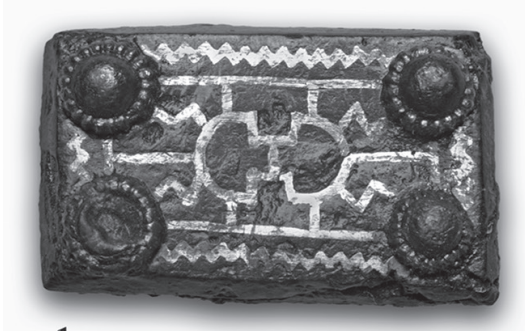

1

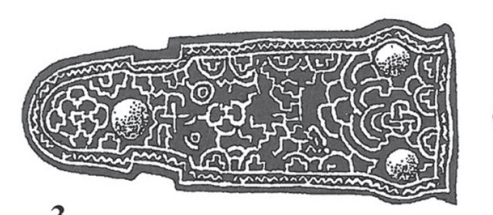

3

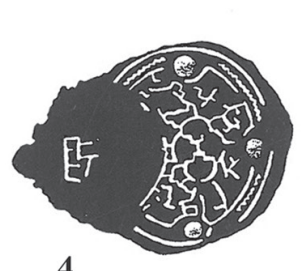

4
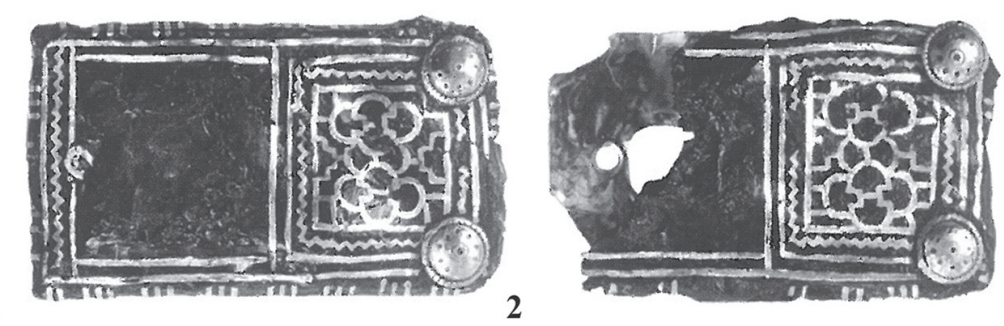

2
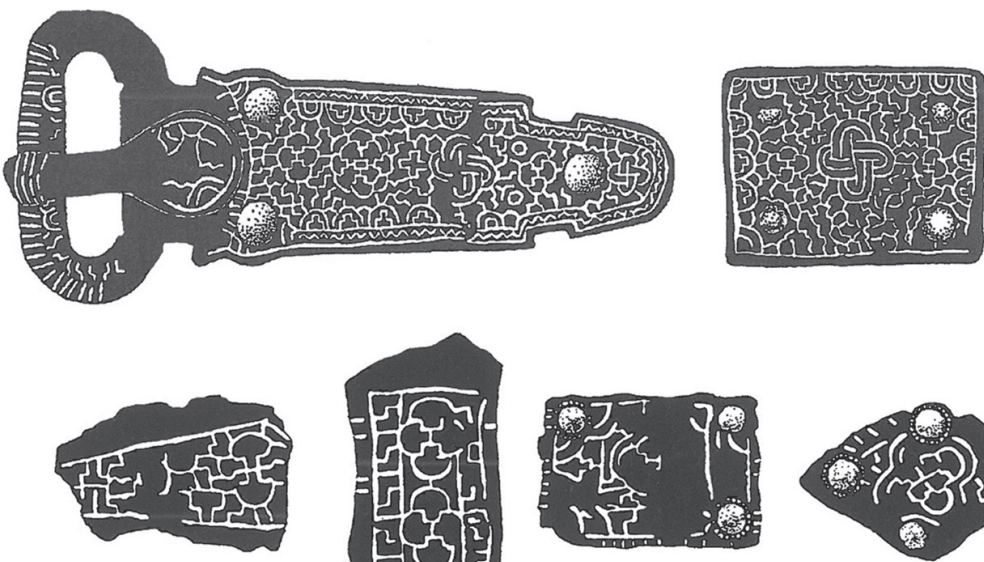

5
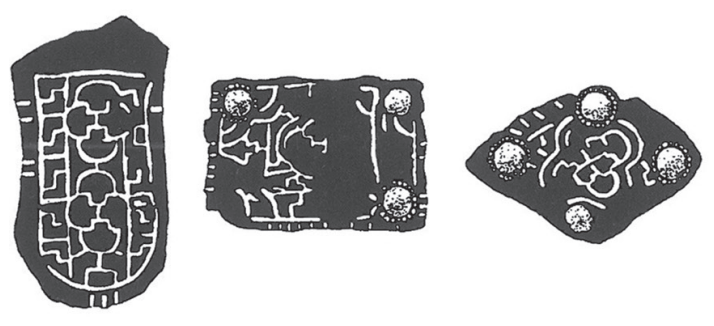

Fig. 1. Beltmounts with mushroom-shaped damascening. 1: Szentendre grave 30 (Photo: HNM);

2: Cividale del Friuli San Mauro grave 44 (after AHumada SILVA 2010); 3: Altenerding grave 712 (after LOSERT 2003);

4: Nocera Umbra grave 27 (after RuPP 2005); 5: Nocera Umbra grave 98 (after RuPP 2005)

${ }^{38}$ See footnote 4 concerning the belt mount from grave 30 :

${ }^{40}$ BÓNA-B. HORVÁtH 2009.

VON FREEDEN 2000, 111-112 and HEINRICH-TAMÁSKA 2005.

${ }^{39}$ BÓNA-B. HoRváth 2009, 130. 
The only datable artefact from grave 34 (Fig. 2) is a rectangular belt mount, decorated with two moustached faces in opposite orientation on its raised middle part. On its shorter sides this artefact is closed by rivet lines, characteristic of the "Weihmörting type". ${ }^{41}$ This type of belt mount is usually found as part of sword belts. ${ }^{42}$ Although the shape of the type is very homogenous, its decoration varies considerably. Therefore the typology developed by Wilfried Menghin is based mostly on the decoration and the material used in crafting. Menghin's collection includes the belt mount from Szentendre, being attributed to the Bülach-Nocera Umbra sub-type. ${ }^{43}$

The belt mounts from Maria Ponsee grave $53^{44}$ (sub-type Herrlisheim-Schwarzrheindorf ${ }^{45}$ ), Pottenbrunn grave $14^{46}$ (sub-type Bülach-Nocera Umbra ${ }^{47}$ ) and Bratislava-Rusovce grave $122^{48}$ (sub-type Weihmörting ${ }^{49}$ ) originate from Langobard artefactual contexts. The piece from Bratislava-Rusovce is decorated by the so-called animal style II, and even the post-568 date came up against the historical dating. ${ }^{50}$ More parallels are known from Langobard Period Italy: Marzaglia, Nocera Umbra (from five graves!) and Cividale „Gallo” sites. ${ }^{51}$ The belt mounts from Italy were dated mostly on a historical basis from the time of the Langobard immigration in 568 to the beginning of the $7^{\text {th }}$ century. ${ }^{52}$

Parallels to the belt mount from Szentendre from the Carpathian Basin are dated without exception to the early Avar Period. ${ }^{53}$ Belt mounts of the Herrlisheim-Schwarzrheindorf and Weihmörting sub-types were found in graves 16, 29 and 39054 at Szekszárd-Bogyiszlói út. Gyula Rosner dated the pieces from graves 16 and 390 to the end of the $6^{\text {th }}$ century. The specimen found in grave 29 , however, was assigned to the turn of the $6^{\text {th }}$ and $7^{\text {th }}$ century. ${ }^{55}$ The same sub-types are known from grave 143 at Nocera Umbra ${ }^{56}$ and grave A from the site of Cividale „Gallo”. ${ }^{57}$ Despite its different length to width ratio - it is not rectangular, but square-shaped - the belt mount from grave 85 of the Kölked-Feketekapu cemetery $\mathrm{B}^{58}$ is very similar in structure to this type (rectangular sword belt mounts). On the basis of its material - gold plated bronze - it is closest to the Bülach-Nocera Umbra type. ${ }^{59}$ Attila Kiss dated burial group IX, including grave 85 , to between 568 and $630,{ }^{60}$ while during the re-evaluation of the cemetery Zsuzsa Hajnal put the grave, based on its Bócsa type ring, to the second quarter of the $7^{\text {th }}$ century. ${ }^{61}$ The most accurate point of reference to the dating of the belt mount type comes from one of the graves from the 2006-2007 excavations at the site of Tiszagyenda. ${ }^{62}$ A Herrlisheim-Schwarzrheindorf type belt mount with mushroom-shaped damascening came to light from the grave of a man buried with his full set of weaponry: spatha, spear, shield. ${ }^{63}$ The grave contained a gold solidus minted in 582-583 by Emperor Mauricius (582-602). ${ }^{64}$ Therefore it cannot be dated prior to 568 .

In the western Merovingian chronologies the dating of this belt mount type is unified. W. Menghin envisaged the appearance of the Bülach-Nocera Umbra sub-type between 530 and 570, on the basis of only

${ }^{41}$ The type was first defined by Hans Zeiß: ZeIss 1934, 39. But the Weihmörting type means only a specific group among the similarly structured belt mounts. W. Menghin uses the term rectangular sword belt mount (rechteckige Schwertgurtbeschlag) for the entire type: MENGHIN 1983, 357 and 360-361. The type is described as "long rectangular sword belt mount" (langrechteckige Schwertguertbeschlag) by Tivadar Vida: VIDA 2000a, 162. Alternatively it was named "box-shaped sword belt mount" (kastenförmiger Spathagurtbeschlag) by other researchers: MüsSEMEIER et al. 2003, 43. Henceforth, in order to avoid misunderstandings, I will use the term rectangular sword belt mount for the entire type, while the Weihmörting type will be used to describe one of its variants (sub-types).

${ }^{42}$ See footnote 1 .

${ }^{43}$ Menghin 1983, 359.

${ }^{44}$ STADLER 2008, 279.

${ }^{45}$ The name of the sub-type with geometric decoration: MENGHIN 1983, 362.

${ }^{46}$ BENEDIX 2015, 68-69. Judith Benedix dated the grave to the last third of the $6^{\text {th }}$ century: BENEDIX 2015, 102-103. The cemetery of Freundorf was used until the beginning of the $7^{\text {th }}$ century. BENEDIX 2015, 92-93.

${ }^{47}$ BENEDIX 2015, 102.

${ }^{48}$ Schmidtová-RutTKay 2008, 385-388.

${ }^{49}$ Menghin 1983, 360. There is no difference in decoration between the Bülach-Nocera Umbra and Weihmörting types. These types are distinguished on the basis of the materials used in crafting, that is gold-plated bronze in the case of the former and bronze (rarely silver plated bronze) in the case of the latter. KAY 2008, 393

${ }^{50}$ HeInRICH-TAmÁsKa 2005, 281 and SchmidtovÁ-RutT-

${ }^{51}$ Tagliaferri 1990b, 377-378. Menghin 1983, 357-362. A fragemntary piece from Cividale-Cella. TAGLIAFERRI 1990b, $377-$ 378. The belt mounts from Marzaglia and graves 27, 32, 48 and 74 at Nocera Umbra represent the Bülach-Nocera Umbra sub-type just as the piece described from Szentendre.

${ }^{52}$ Zeitstufe 1 and 2: BIERBRAUER 2008, 125.

${ }^{53}$ Detailed analysis and definition: VIDA 2000a.

${ }^{54}$ Grave 16: Rosner 1999, 12-13 and Taf. 2. Grave 29:

RosNer 1999, 14 and Taf. 3. Grave 390: RosNer 1999, 54 and Taf. 28

${ }^{55}$ RosNer 1999, 111-112.

${ }^{56}$ RupP 2005, Taf. 150.

${ }^{57}$ BROZZI 1970, 102-103.

${ }^{58}$ Kiss 2001, 29-37.

${ }^{59}$ About the connections of the belt mount in detail: KISS 2001, 304-317

${ }^{60}$ KISS 2001, 345

${ }^{61}$ Phase 4: HAJNAL 2013, 629-630.

${ }^{62}$ Unpublished grave and cemetery: Kocsis 2010, 17-19.

${ }^{63}$ Kocsis 2010, 17-18.

${ }^{64}$ Somogyi 2014, 203. 
two finds, ${ }^{65}$ but dated every grave that included this kind of mount type to between 580 and $620 .{ }^{66}$ Ursula Koch came to the same results during the analysis of the Schretzheim, ${ }^{67}$ Pleidelsheim ${ }^{68}$ and Klepsau materials. ${ }^{69}$ In the Lower Rhine region the belt mount type is dated to between $565-580 / 90,{ }^{70}$ but it is possible that it appeared earlier, pre-dating $565 .^{71}$

Parallels to the sword belt mount from grave 34 at Szentendre are dated to after 568. I propose a dating of the grave as the last third of the $6^{\text {th }}$ century, although the pre-568 dating could not be ruled out with complete certainty.

A rectangular belt mount, decorated with geometric damascening came to light from grave 30 (Fig. 1) at Szentendre. ${ }^{72}$ It was fastened to the belt with the help of four rivets at its corners. The dating is based on both technology and pattern of the decoration on the belt mount. ${ }^{73}$ Its central motif is the combination of two mushroom shapes with opposing orientations. ${ }^{74}$

Simple, rectangular belt mounts appeared as part of three-piece sword belt sets (dreiteilige Gürtelgarnituren) consisting of a buckle, buckle counter-plate and rectangular belt mount. They were dated to the end of the $6^{\text {th }}$ and beginning of the $7^{\text {th }}$ century. However this belt type could not alwasy be unambiguously identified, as both the belt buckle and the buckle counter-plate often tend to be missing because of contemporaneous disturbations to the grave. The structure of such belts therefore cannot be safely used in stylistic dating.

Several buckles and belt mounts with mushroom-shaped damascening are known from the western Merovingian world. The belt mounts from the cemetery of Schretzheim ${ }^{75}$ were dated to between 565 and $620 / 30$ by U. Koch. ${ }^{76}$ She arrived at similar dates in the case of grave 168/70 from Pleidelsheim, ${ }^{77}$ which contained a belt buckle showing mushroom-shaped damascening. ${ }^{78} \mathrm{~A}$ three-piece belt with the same type of decoration came to light from grave 712 at Altenerding. ${ }^{79}$ Hans Losert dated that burial to the last quarter of the $6^{\text {th }}$ century on the basis of the mushroom-shaped decoration. ${ }^{80}$

Multiple artefacts decorated with mushroom-shaped damascening came to light from the cemetery of Niederstotzingen. All parts in the three-piece sword belt set recovered from grave 12 were decorated this way. On the other hand, this motif can also be found on the belt buckle and mount from grave 9 and the belt buckle and counter-plate from grave 1 as well. ${ }^{81}$ The cemetery was begun and remained in use during the $7^{\text {th }}$ century. ${ }^{82}$ The graves that contained metalwork decorated using mushroom-shaped damascening predate graves 4, 5, 6 and 7 . Based on their stylistic connections to Avar material culture these latter were dated to the middle of the $7^{\text {th }}$ century. ${ }^{83}$

Two graves that contained coin finds are of help in the dating of this decoration in the Lower Rhine region: a grave from Morken which revealed a Frankish copy of a Byzantine tremissis minted around 600 and grave II.

${ }^{65}$ See the seriation tables in W. Menghin's work: MENGHIN 1983. Grave 39 from Bifrons was dated on the basis of a shield-ontongue belt buckle (Schilddornschnalle) and shield-shaped mounts (schildförmige Gürtelhaften) although these were still in use at the very end of the $6^{\text {th }}$ century. Grave 115 from Dieu sur Meuse should be dated to the third quarter of the $6^{\text {th }}$ century on the basis of its plate-ontongue belt buckle (Plattendornschnalle).

${ }^{66}$ Menghin 1983, 59. W. Menghin has dated this sub-type between 570/80-620/30 (Zeitgrubbe D). MENGHIN 1983, 146. Although his collection included the piece from Szentendre, he never dealt with it in detail, because it wasn't published at the time.

${ }^{67}$ A Bülach-Nocera Umbra type belt mount came to light from grave 127 at Schreztheim. It could be dated to between 565 and $590 / 600$ using the evidence of the mounts and a spear preserved in this the grave: КоCH 1977, 31-32, 39 and Taf. 29.

${ }^{68}$ Kastenförmige Beschlag (Y13). Süddeutsche-Phase 7: Косн 2001, 62, 87.

${ }^{68}$ Grave 6 at Kelpsau contained three belt mounts decorated with different types of motifs, one of them with two moustached male faces in opposing orientations. The grave is dated to the last third of the $6^{\text {th }}$ century: KocH 1990, 28-35, 235 and Taf. 5-8.

70 Spaß: kastenförmiger Spathagurtbeschlag. Phase 5. MÜSSEMEIER et al. 2003, 42 and 105.
${ }^{71}$ Although not one of them is dated to before 565. MüSSEMEIER et al. 2003, 42.

72 Szentendre grave 30: BónA-B. HoRváth 2009, 104, 106-107 and Taf. 43.

${ }^{73}$ The belt mount fits within the first group defined by Orsolya Heinrich-Tamáska, showing Germanic traits both in technology and ornamentation: HEINRICH-TAMÁSKA 2005, 125.

74 Pilzmuster: MuHL 1994, 42.

75 The rectangular counter-plate from grave 127 and the three-piece sword belt from grave 580 from the Schretzheim cemetery have this type of decoration. Grave 127: KocH 1977, Taf. 29.; Grave 580: Косн 1977, Taf. 152.

${ }^{76}$ Grave 127, Phase 3 (565-590/600) Grave 580, Phase 4 (590/600-620/30): КосH 1977, 39 and 46.

${ }^{77}$ SD-Phase 7 (580-600), Косн 2001, 485 and Taf. 67.

${ }^{78}$ SD-Phase 7 (580-600) Косн 2001, 62 and 87. U. Koch named this decoration Zellenmuster, so that in this case the emphasis is not on the shape, Code M87: Косн 2001, 62.

${ }^{79}$ SAGE 1984, Taf. 96-97. and Losert 2003, 329.

${ }^{80}$ LOSERT 2003, 331.

${ }^{81}$ PAUlsen 1967, Taf. 31-34.

82 Paulsen 1967, 155 and Werner 1973, 278.

${ }^{83}$ PAULSEN 1967, 55. 

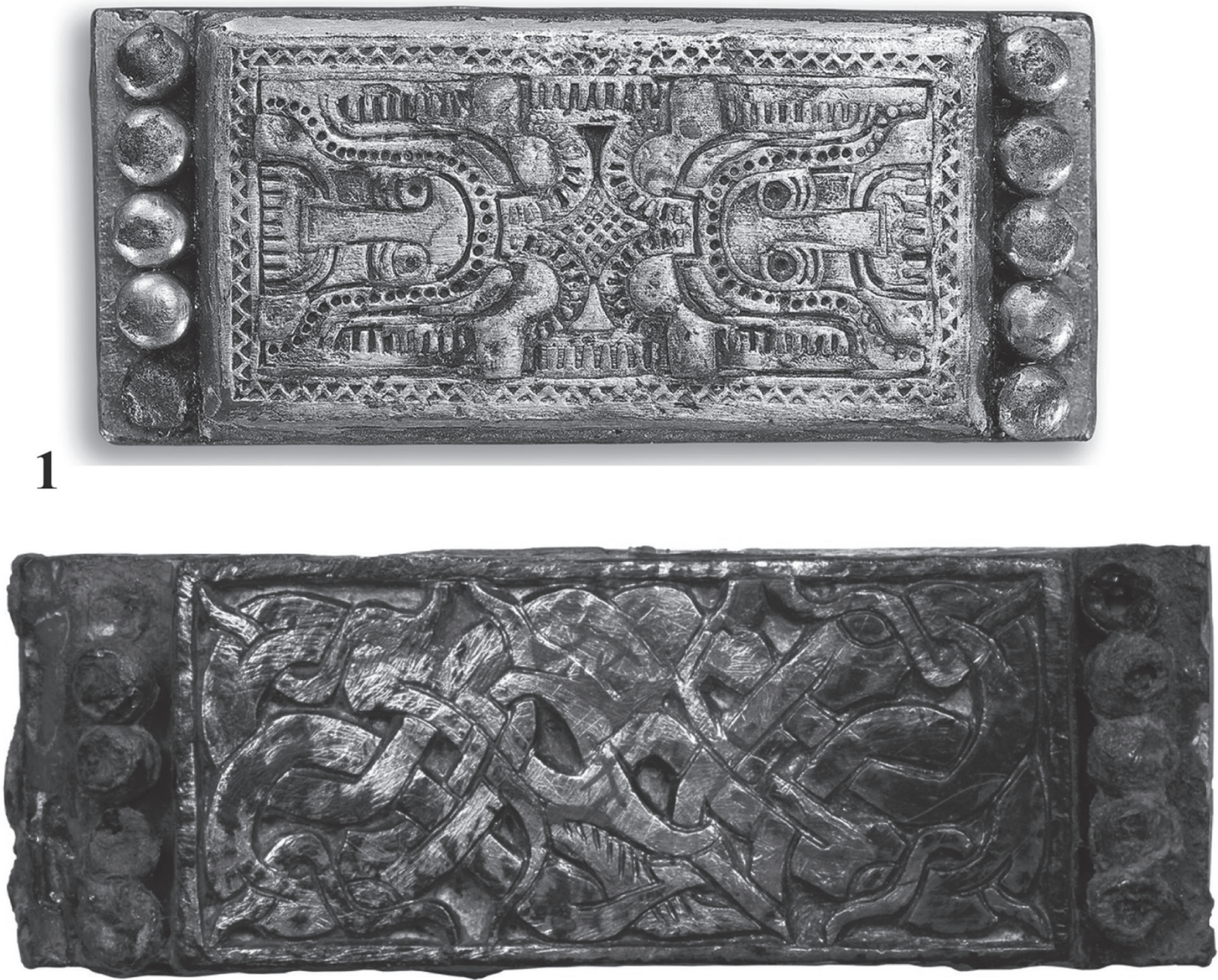

2

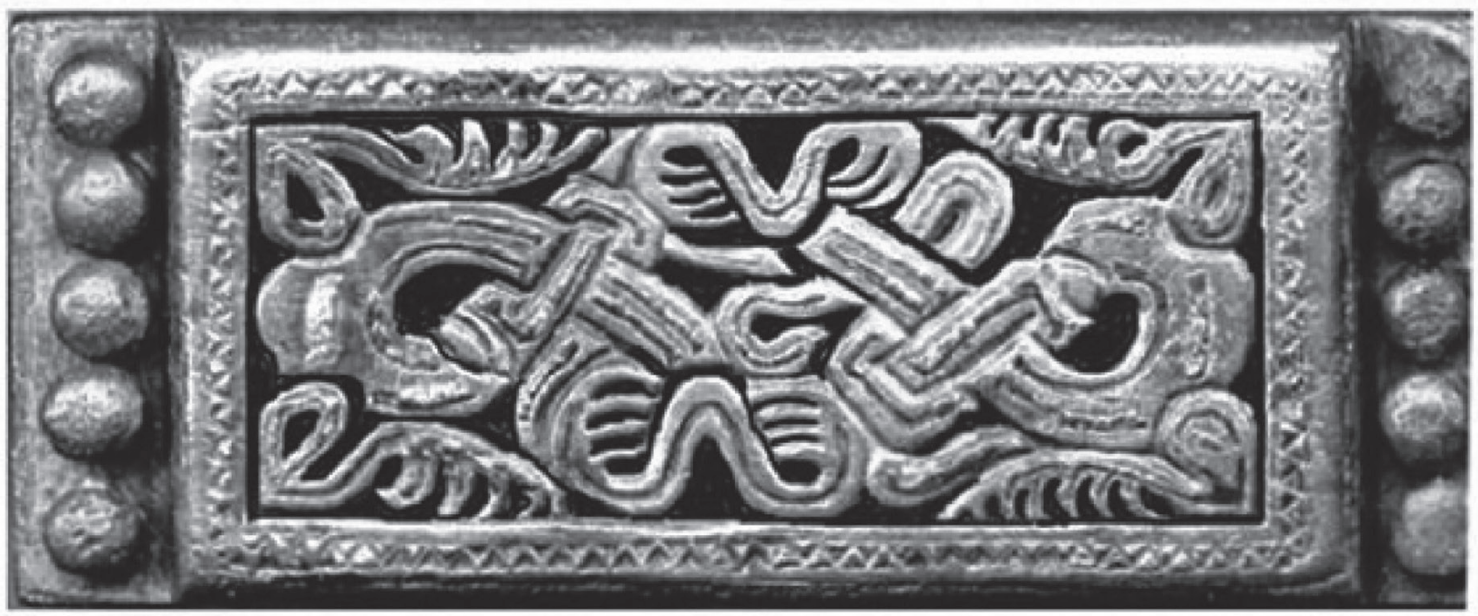

3

Fig. 2. Rectangular swordbelt mounts. 1: Szentendre grave 34 (Photo: HNM); 2: Pottenbrunn grave 14 (after BENEDIX 2015); 3: Bratislava-Rusovce grave 122 (after Schмidtová et al. 2009) 
at Wallerstädten that yielded a solidus of Emperor Tiberius II Constaninus (578-582). ${ }^{84}$ These burials are dated between 585 and $610 .{ }^{85}$

The already mentioned Herrlisheim-Schwarzrheindorf type belt mount from Tiszagyenda was decorated using mushroom-shaped damascening as well. This is the only direct ornamentation parallel to the belt mount from grave 30 of the Szentendre cemetery that I am aware of in the Carpathian Basin. I have already discussed the dating of the burial from Tiszagyenda previously; here I would only like to repeat that it could not have been deposited before the 580s.

There are several parallels to the belt mount from grave 30 at Szentendre dated to the Langobard Period of Italy. The mushroom-shape is characteristic of the so-called pseudo-cloisonné style of damascened artefacts, which draws its repertoire partially from fine metal work decorated using glass and gemstone inlay. ${ }^{86} \mathrm{~A}$ belt buckle and a strap-end from grave $27^{87}$ and the belt from grave $98^{88}$ at the cemetery of Nocera Umbra were decorated using mushroom-shaped damascening. One of the belt mounts from grave 98 is a close parallel to the belt fitting from Szentendre not only in terms of decoration, but in its shape and size as well. The mushroom motif was identified in the cemetery of Cividale del Friuli San Mauro: two belts with several parts (buckle, counter-plate, strap-end etc.) decorated using mushroom-shaped damascening came to light from graves 41 and $44 .{ }^{89}$ Both of these pieces from Italy were dated to the very end of the $6^{\text {th }}$ or beginning of the $7^{\text {th }}$ century. ${ }^{90}$

On the basis of its decoration, the belt mount from grave 30 in Szentendre can be dated to the final decades of the $6^{\text {th }}$ or beginning of the $7^{\text {th }}$ century.

Grave 81 (Fig. 3) at Szentendre contained a pressed silver sheet artefact. It was placed next to the left ankle of the deceased, so it was interpreted by I. Bóna as a shoe fitting. ${ }^{91}$ The drawing of the object ${ }^{92}$ is hard to understand, because, according to I. Bóna, it was damaged during the course of restoration. Object 12a is decorated with four petals (?), while objects $12 \mathrm{~b}$ and $12 \mathrm{c}$ are leaf-shaped. The latter piece is fragmentary, but originally they formed all part of the same artefact.

A similar artefact is known from the Isola Rizza treasure hoard. In addition to the gold shield-on-tongue buckle, three leaf-shaped belt mounts made of gold were found as well. They were fastened to the belt with loops on the back. ${ }^{93}$ On the basis of a characteristic silver plate, this hoard was dated to the end of the $6^{\text {th }}$ or beginning of the $7^{\text {th }}$ century by Otto von Hessen. ${ }^{94}$ One of the moulds from the press mould set found in the horseman's burial at Fönlak (Felnac) - dated to the beginning of the $7^{\text {th }}$ century ${ }^{95}-$ is parallel to a similar artefact from Szentendre. ${ }^{96}$ There is another very similar press mould in the collection of Nándor Fettich, but its origin is unknown. ${ }^{97} \mathrm{~A}$. Kiss wrote about a shell-shaped strap-end (muschenförmige Riemenzunge) with regard to an analogous specimen from

${ }^{84}$ SIEGMUND 1998, 526.

${ }^{85}$ Niederrhein Phase 7 (585-610): SiEgmund 1998, 206207. Revised: Phase 6 (580/90-610/20): MüSSEMEIER et al. 2003, 78 On the basis of the structure of these belts M. Martin dated the graves to the beginning of the $7^{\text {th }}$ century: MARTIN 2008, 157.

${ }^{86}$ Giostra 2000, 34-35. Mushroom-shape as an ornament is not exclusively linked to damascening, it can be found as inlay as well. The belt buckle and strap-ends found in the mound 1 at Sutton Hoo and several artefacts from the Staffordshire Hoard are decorated with mushroom-shaped inlay. On the basis of the finds from Sutton Hoo Rupert Bruce-Mitford suggests that mushroom-shaped inlay originated from Anglo-Saxon England. Birgit Arrhenius explained the exceptional quantities and quality of inlay with the expectations of high ranking customers. Artefacts decorated with mushroom-shaped inlay from the Continent are contemporaneous with the Anglo-Saxon pieces, sometimes even predating them. From Langobard artefactual assemblages the S-brooch from Cividale-Cella is known to have mushroom-shaped inlay. This specimen was dated to the beginning of the 7th century: ARRHENIUS 1985, 73 and 154-155; BRUCE-MITFORD 1949; 603. LEAHY-BLAND 2009, 31-35, 42; TAGLIAFERRI 1990b, 430.

${ }^{87}$ RUPP 2005, 39-41 and Taf. 44-46. The grave contained a Bülach-Nocera Umbra type belt mount as well. The structure of the belt is difficult to define, Caterina Giostra interpreted it as a four-piece sword belt set: GIOSTRA 2000, 34.

${ }^{88}$ RuPP 2005, 118-120 and Taf. 112-113. The belt buckle or counter-plate, strap-end and three, diffrently shaped belt mounts were all decorated in the same way. The pyramid mounts belonging to the belt remained undecorated.

${ }^{89}$ Grave 41: Ahumada Silva 2010, 85-94 and tav. 43-46. There are two different belt sets in the grave decorated with damascening. Grave 44: AHumada Silva 2010, 105-117 and tav. 56-62.

${ }^{90}$ Both the ornamental and chronological aspects of decoration were analysed in detail by C. Giostra. She used western Merovingian paralells as reference. Her collection includes the belt mount from Szentendre, but she never discusses its dating. GIOSTRA 2000, 35-37. See also: Zeitstufe 1 and 2: BIERBRAUER 2008, 125.

${ }^{91}$ BÓNA-B. HoRvÁth 2009, 130.

92 BÓNA-B. HoRvÁTH 2009, Taf. 54.

${ }^{3}$ Von Hessen 1968, 39 and Taf. 40.

${ }^{94}$ Von Hessen 1968, 70.

${ }^{95}$ Martin 1990, 67. RÁCZ 2014, 39-43.

96 TĂNASE 2010, Taf, 363. and FETTICH 1926, Taf. 5/42.

${ }^{97}$ FeTtich 1926, Taf. 7/6. 
grave 175 in the cemetery of Kölked-Feketekapu A and dated it to the first half of the $7^{\text {th }}$ century. Based on its zone of geographical distribution, A. Kiss dated this type to the Avar Period, but considered it a Byzantine product. ${ }^{98}$ A similar piece was found in grave 94 at Linz-Zizlau. It was described as a belt mount with palmette decoration by Hertha Ladenbauer-Orel. Unlike the specimen from Szentendre, this piece is cast and is dated by association with the belt in the same grave to between 600 and 620/30. ${ }^{99}$

There are no direct parallels to the silver sheet artefact found in grave 81 at Szentendre, but similar pieces help dating it to the beginning of the $7^{\text {th }}$ century, so the same way as graves 30 and 34, grave 81 could be dated to after 568 as well. Moreover it is also possible that this is the earliest appearance of the form. I find it important to note that while on the one hand the parallels are press moulds, on the other they may have been used in different
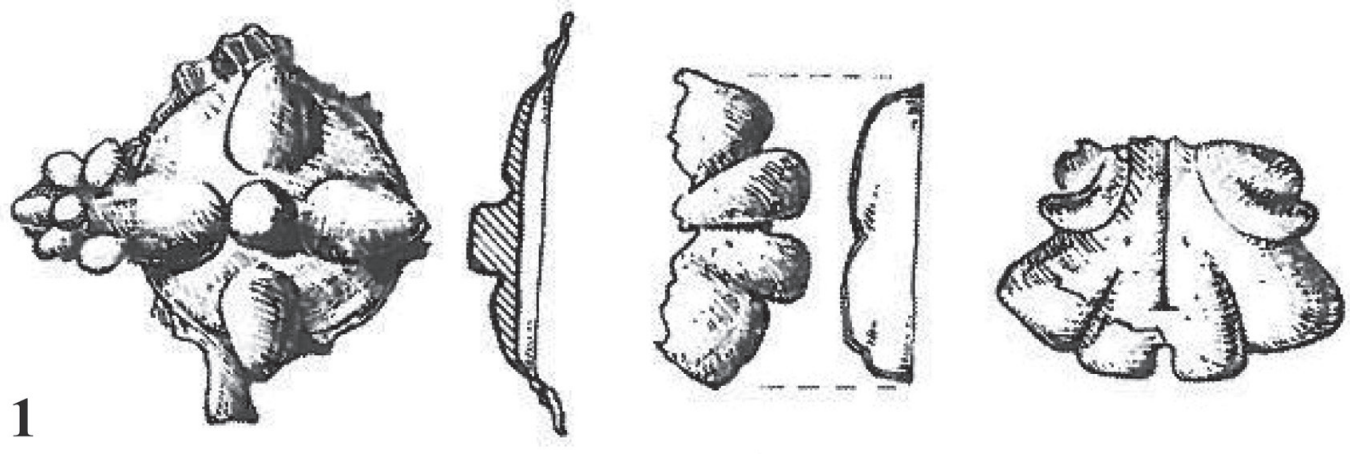

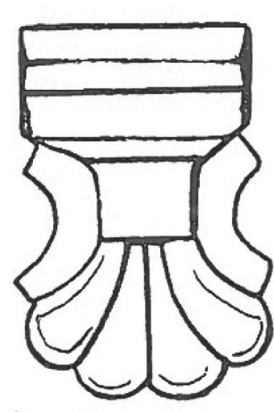

2

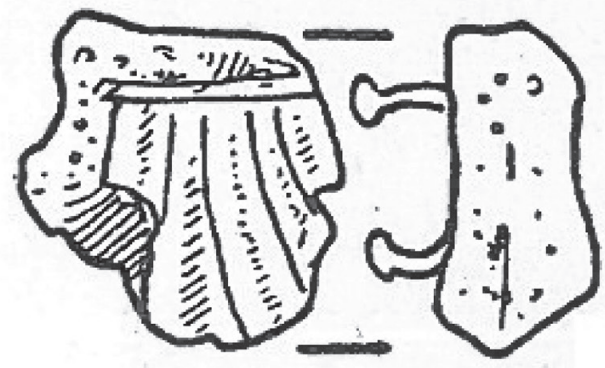

4

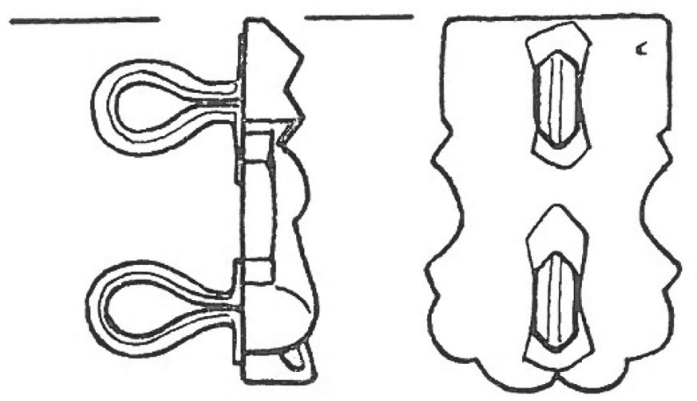

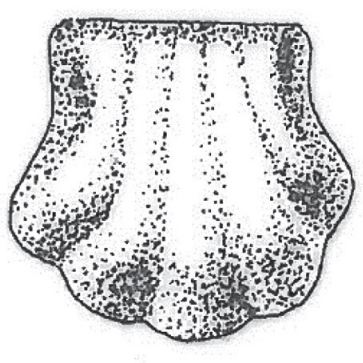

3

Fig. 3. The shoefitting from Szentendre grave 81 and its parallels. 1: Szentendre grave 81 (after BÓNA-B. HoRVÁTH 2009); 2: Isola Rizza (after Von Hessen 1968); 3: Felnac (after RÁcz 2014); 4: Linz-Zizlau grave 94 (after LADENBAUER-OREL 1960); 5: Kölked-Feketekapu A. grave 175 (after KISs 1996)

${ }^{98}$ KISS 1996, 225 and Taf. 44.

${ }^{99}$ MARTin 1990, 74 and 84. 
ways. The find from Szentendre seems to be a shoe fitting, while a similar artefact found in Isola Rizza is a belt mount. At the site of Kölked a similar piece was identified as a strap-end.

Graves 30 and 81 are located on the edge of the Szentendre cemetery, the former in the east, while the latter in the north. Their locations thus suggest that they may have been the latest burials. The picture is more complex in the case of grave 34, located in the middle of the cemetery. The graves around grave 34 (graves 38 and 41 and horse grave 47) are not datable in the absence of grave goods or lack of characteristic artefacts (grave 45). It is imaginable that these non-datable graves are parts of a younger burial group, deposited in the late $6^{\text {th }}$ century.

If we reckon with grave robberies in 568 - as has been widely accepted in Hungarian research - then we must date graves 30 and 34 to $540 / 50$ on the basis of their advanced status of the decomposition of the bodies. The bones were mixed up at the time of the disturbance of the burial. However, the grave goods analyzed in detail above do not support such an early dating.

\section{2. The cemetery of Tamási-Csikólegelö}

Grave 34 from Tamási (Fig. 4) contained a belt set composed of 13 pieces: an iron shield-on-tongue buckle decorated with a round buckle plate, six smaller and four larger rectangular iron belt mounts, a strap-end made of a back-folded iron sheet and a bronze strap-holder. Three rivets fixed the buckle to the leather strap and the belt mounts were attached by four rivets each. The structure of this belt set is closest to those of the three-piece ${ }^{100}$ or four-piece belts, in which aside from the belt buckle, rectangular belt mount and (in this case asymmetric) buckle counter-plates appear. The belt set under discussion here was expanded with further rectangular belt mounts showing a unique taste.

The belt buckle or the belt set has no real parallels in Langobard Pannonia, but it is widely known in the western Merovingian world. Its dating is based on the belt structure and the design of the buckle (unadorned, with a fixed round buckle plate made of iron). The buckle type typically occurred in the last third of the $6^{\text {th }}$ century. A few earlier specimens are known, but used together only with a single rectangular belt mount (two-piece belt). ${ }^{101} \mathrm{~A}$ very similar belt buckle came to light as a part of a three-piece belt set from the grave 376 at Altenerding. ${ }^{102}$ The strapholder of that same belt is a very close parallel to that of the Tamási specimen as well. The deceased was buried between 575 and $625 .{ }^{103}$ On the basis of coin finds recovered in association with such belts, M. Martin dated this type to between the last third of the $6^{\text {th }}$ and the first decades of the $7^{\text {th }}$ century. ${ }^{104}$ The dates are very similar in the Lower Rhine region, ${ }^{105}$ in the cemetery of Schretzheim in South Germany ${ }^{106}$ and in Italy: parallels are known from Colosomano ${ }^{107}$ and grave 18 at Cividale-Santo Stefano in Pertica. ${ }^{108}$

In the Carpathian Basin, a parallel belt buckle was found in grave 2000/148 at Keszthely-FenékpusztaPusztaszentegyházi dűlő without any other belt mounts. ${ }^{109}$ Róbert Müller dated the buckle and the burial to the end of the $6^{\text {th }}$ century. ${ }^{110}$ Grave 82 from Kölked-Feketekapu cemetery B, dated between 568 and 630, contained a similar belt buckle as well. ${ }^{111}$

Similarly to the burials the analyzed in Szentendre, grave 34 is located on the edge of the Tamási cemetery.

${ }^{100}$ Not counting the folded iron sheet used as strap-end as a structural part of the belt.

${ }^{101}$ A single specimen in grave 166 at Pleidelsheim was dated to phase 7 (580-600). Code: MCODE86: Gürtelgarnitur, ein- bis dreiteilig, runder Schnallenbeschlag: Косн 2001, 62, 87, 483-484 and Taf. 67. Part of a two-piece belt for example from graves 203 and 257 at Schretzheim, dated between 565 and 590/600: Косн 1977, 46 and Taf. 54; 60 and Taf. 69. Concerning their dating: Косн 1977, 21-25 and 35-47. In the Lower Rhine region the type occurred at the end of the $6^{\text {th }}$ century: Frank Siemgund's type Gür4.1 (ein- oder zweiteilige Gürtelgarnitur mit halbrundem Beschlag; Rückenbeschlag halbrund oder hochrechteckig) between 585 and 610. SIEGMUND 1998, 30-31 and 205.

102 SAGE 1984, 106 and 45. t.

${ }^{103}$ Eiserne Gürtelgarnitur mit volrundem bis dreiviertelrundem Beschläg. The belt/belt buckle from Tamási corresponds to variant 1: LOSERT 2003, 321-324.
${ }^{104}$ MARTIN 2008, 157-161 and 172.

105 Type Gür4.2: Dreiteilige Gürtelgarnitur mit halbrundem Beschlag; Rückenbeschlag halbrund oder hochrechteckig. SIEGMUND 1998, 31. based on F. Siegmunds work the the type is dated a little earlier, from 565: MÜsSEMEIER et al. 2003, 20 and 105-106.

106 Three-piece belts from garves 248 and 482 are dated to phase 4 , so to early $7^{\text {th }}$ century. КосH 1977,58 and Taf. $65 ; 103$ and Taf. 125. Dating: Косн 1977, 26 and 35-47.

107 TAgLiaferri 1990a, 112.

108 TAGLIAFERRI 1990b, 419-421.

${ }^{109}$ MÜller 2014, 73, and Taf. 25.

${ }^{111}$ MÜLLER 2014, 136-137.

${ }^{111}$ KIss 2001, 27-28, 345, and Taf. 28. 


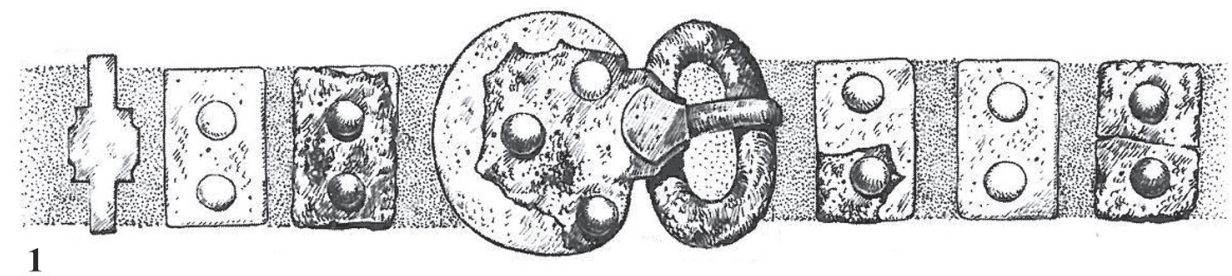

$$
1
$$
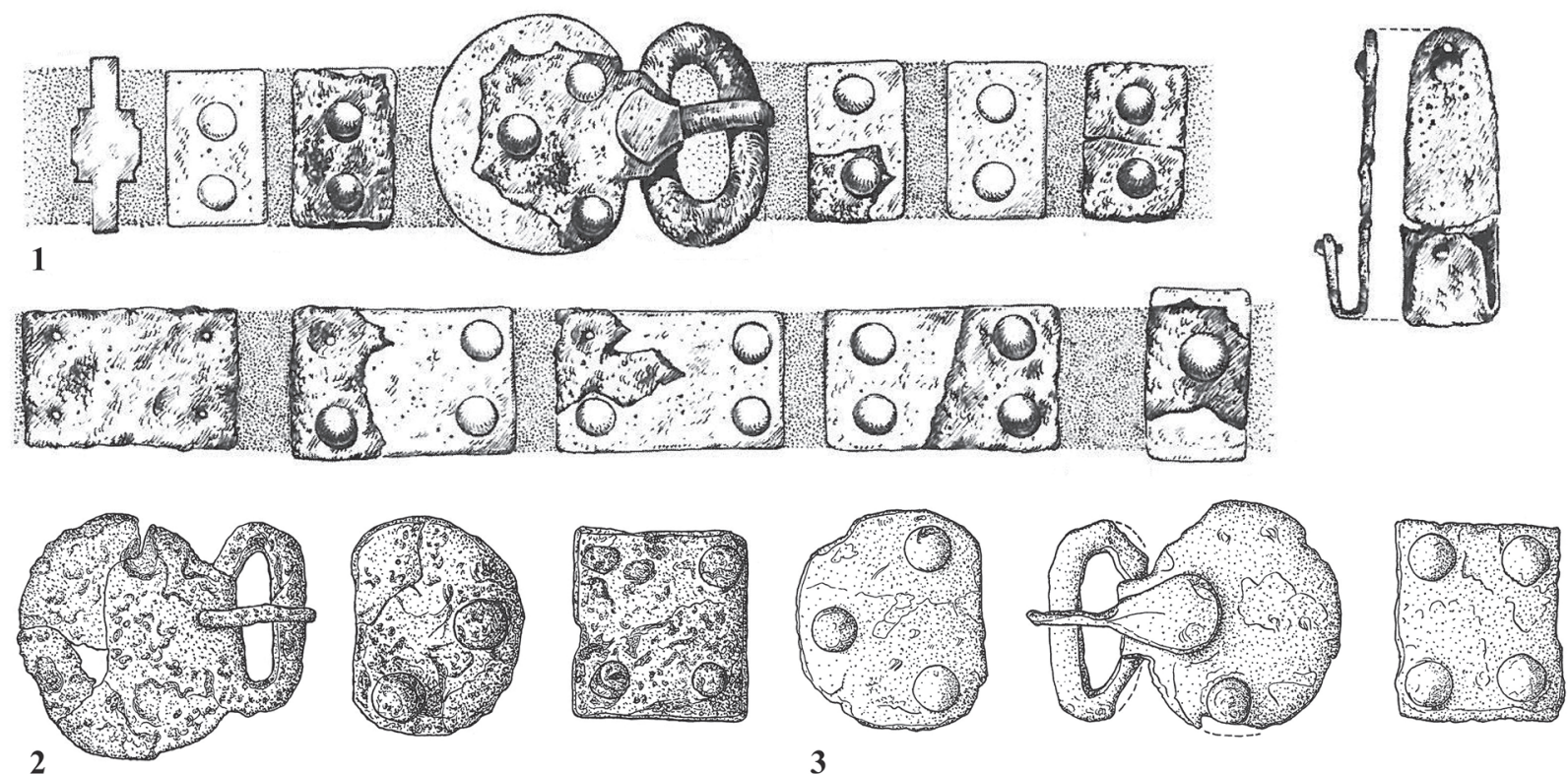

3
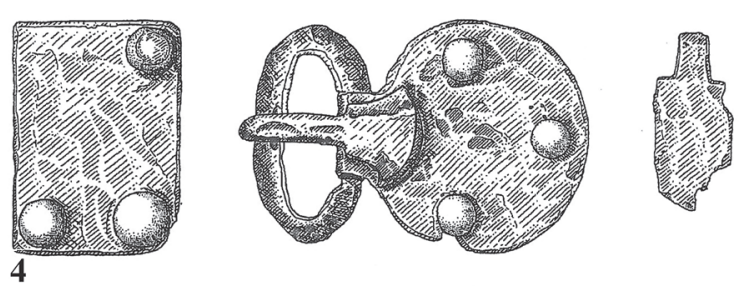

Fig. 4. The beltfrom Tamási grave 34 and some of its parallels. 1: Tamási grave 34 (after BónA-B. HoRváth 2009);

2: Schretzheim grave 248 (after КосH 1977); 3: Schretzheim grave 482 (after КосH 1977); 4: Altenreding grave 376 (after LOSERT 2003)

\section{3. The cemetery of Gyirmót-Homokdomb}

A bronze belt buckle with oval-shaped frame came to light from grave 17 at Gyirmót. ${ }^{112}$ The buckle and the buckle-plate were fixed, i. e. cast together. This find had a U-shaped buckle-plate with a peak at the point where the tongue connects. There are no close parallels to this find in the Langobard Period of Pannonia yet. Its shape shows similarities with Byzantine type belt buckles.

The belt buckle from Gyirmót is closest to type D12 (oval-shaped buckle with fixed, round-shaped buckleplate decorated with palmette motif) ${ }^{113}$ and D14 (oval-shaped buckle with fixed, three-quarter circle-shaped buckleplate) ${ }^{114}$ from the typology of belt buckles of Byzantine origins developed by Mechtild Schulze-Dörrlamm. The specimen from Gyirmót, however does not have the small tongue on its buckle-plate opposite to the frame, as would be characteristic of Byzantine types. ${ }^{115}$ Another difference compared to type D12 is that the buckle from Gyirmót is undecorated. Although type D14 also tends to be decorated, at least some undecorated pieces are also known. ${ }^{116}$ The occurrence of type D12 is dated to around 580, while that of type D14 from 600 onwards. These types were given up at the turn of the $7^{\text {th }}$ and $8^{\text {th }}$ centuries. ${ }^{117}$

${ }^{112}$ TOMKa 2005 and TOMKa 2008.

113 Ovale Schnallen mit rundlichem Beschläg und Palmettenzier. SCHULZE-DöRRLAMm 2002, 171-179. The same as J. Werner's Syracuse-type. WeRNER 1955, 37.

${ }^{114}$ Ovale Schnallen mit dreifirtelkreisförmigen Beschläg. SCHULZE-DörRLAMm 2002, 181-184.
${ }^{115}$ The two types were distinguished by Ellen Riemer: RIEMER 1995, 780.

${ }^{116}$ An undecorated piece from Asia Minor, the tongue on the buckle-plate is barely visible: SCHULZE-DöRRLAMM 2002, 182.

${ }^{117}$ SCHULZE-DörRLAMm 2002, 247. 
A parallel is known from Italy, grave A from the cemetery of Cividale Gallo. ${ }^{118}$ That specimen is undecorated, but its shape is slightly different: the buckle-plate is round and the afore-mentioned tongue is accentuated. Similar pieces came to light from grave 87/4 at Selvicciola ad Ischia di Castro ${ }^{119}$ and from grave $74 \mathrm{~b}$ at Romans d'Isonzo. ${ }^{120}$ These were, however fixed to the belt with the help of loops, not using rivets like in the case of the Gyirmót exemplar. Several similar belt buckles are known from the workshop excavated at Crypta Balbi in Rome. ${ }^{121}$ The afore-mentioned buckle types spread to Italy during the second half of the $6^{\text {th }}$ century. However, in some cases earlier distribution during the first half of the $6^{\text {th }}$ century cannot be excluded. ${ }^{122}$

Parallels from the Carpathian Basin are known from Gepidic cemeteries and from the Avar Period. A similarly shaped belt buckle came to light from grave 197 in the third cemetery of Bratei. It was interpreted as Gepidic and dated to the second half of the $6^{\text {th }}$ or beginning of the $7^{\text {th }}$ century. ${ }^{123}$

M. Schulze-Dörrlamm mentions three type D14 belt buckles from the Avar Period, ${ }^{124}$ but these are different in several aspects. They are decorated and their shapes as well as length to width ratios are different from that of the belt buckle found in Gyirmót. ${ }^{125}$ The same holds true for the buckles from grave 284 of cemetery B at Kölked-Feketekapu ${ }^{126}$ and grave 250/a at Zamárdi-Rétiföldek. ${ }^{127}$

Based on the afore-mentioned parallels I consider the Gyirmót belt buckle not of western Merovingian, but of Byzantine origin. It is impossible to tell, however, whether it was a local or imported product. Péter Tomka noticed early Avar Period parallels to this buckle as well, but dated the grave and the entire cemetery prior to 568 noting that grave 17 is possibly the youngest of all the burials. ${ }^{128}$ A detailed analysis of relative chronology will only be possible after the publication of the cemetery.

\section{EARLY AVAR PERIOD CEMETERIES IN WESTERN HUNGARY IN LIGHT OF POPULATION CONTINUITY}

Connections between Langobard and early Avar Period cemeteries show a complex picture. In addition to the already mentioned cemetery from Várpalota there are further sites where burials interpreted as Langobard and Avar co-occur. In several important early Avar Period cemeteries the connection of material culture to the western Merovingian world has already been documented. ${ }^{129}$ According to the "ethnic" approach, a possible interpretation of this connection is that various Germanic groups co-occurred in the Carpathian Basin during the early Avar Period. ${ }^{130}$

The detailed presentation of this complex issue exceeds the scope of my paper. I would only like to highlight some neglected examples that could provide details of vital importance for the topic and connect it to well known sites, all too often having complex and unclear interpretations.

${ }^{118}$ TAGLIAFERRI 1990b, 385. Péter Tomka has already mentioned it as a parallel: TOMKA 2005, 250

${ }^{119}$ INCITTI 1997, 6/11. f.

${ }^{120}$ Degrassi 1989, 58 and tav. IX-X.

${ }^{121}$ RICCI-LUCCERINI 2001, 376 and 378. (cat. II. 4599 and II. 4579.)

${ }^{123}$ RIEMER 2000, 149-152.

${ }^{124}$ BÂRZU 2010, 156-158 and 58f. and Taf. 34.

${ }^{124}$ The buckle-plate is larger in comparison with the frame than in the case of the buckle from Gyirmót. Early Avar Period buckles were fixed to the belt using rivets, like in the case of the Gyirmót specimen.

${ }^{125}$ Aradac grave 1: decorated bronze belt buckle. Sandor Nadj dated the cemetery between the second half of the $6^{\text {th }}$ century and the beginning of the $7^{\text {th }}$ century. He considered that it had been continuously used by both Gepids and Avars: NADJ 1959, 102 and Taf. 1/5. Csengele (Szeged-Csengele Feketehalom) grave 30: decorated bronze belt buckle with oval-shaped frame and fixed buckle-plate. TöRÖK 1981, 44 and Taf. IV/13. Gyula Török dated the beginning of the cemetery to around 600. TöRÖK 1981, 61. Feketic: gold-plated bronze buckle as part of a multi-part belt set from the burial of a horseman, dated to the first half of the $7^{\text {th }}$ century: VINSKI 1958, 60 and Taf. 7.

${ }^{126}$ Kiss 2001, Taf. 71.

${ }^{127}$ Kiss 2001, Taf. 71.

${ }^{128}$ The dating of the grave is based on the widely accepted theory that Langobard Period cemeteries were robbed by the Langobards themselves before their departure. The human remains remained intact during the robbing. The body was moved as whole, so the disturbance could not have taken place long before 568. Based on the kind personal communication by P. Tomka.

${ }^{129} \mathrm{~A}$. Kiss and M. Martin began the systematic collection: Kiss 1992, MARTIN 1990, MARTIN 1996.

${ }^{130}$ Among others: FetTich 1964, 90-96; Kiss 1996, Kiss 2000, Kiss 2001; MÜLLER 2000, MÜLLER 2014; RosNER 1999. 


\section{1. Grave 196 from the cemetery of Jutas}

In the debate concerning the Várpalota cemetery, the locations of the graves were used as arguments for as well as against continuity as they were not spatially separated. They did not create a unified cemetery and the material cultures of the two periods could never be found within the same grave. The same arguments can be made in the case of the cemetery at Jutas, where researchers interpreted grave 196 as clearly Langobard while the rest of the cemetery was considered Avar. ${ }^{131}$

The dating of grave 196 is ambiguous. Its S-shaped brooch belongs to the type of Várpalota grave 19, which was identified as the later type of S-brooches by I. Bóna. ${ }^{132}$ He dated its appearance to around 540 in light of the animal style I decoration between the areas of inlay. ${ }^{133}$ This type has several parallels from both Langobard Period Pannonia and Italy, ${ }^{134}$ where V. Bierbrauer associated it to the first generation of Langobards. ${ }^{135}$ Both western Merovingain chronologies ${ }^{136}$ and Jaroslav Tejral ${ }^{137}$ date the type from the second third of the $6^{\text {th }}$ and the beginning of the $7^{\text {th }}$ century as well.

Based on their animal head endings and half-round heads each decorated with seven knobs, the pair of bow brooches from grave 196 is closest to the Várpalota 5-Udine-Čelákovice type. According to the inlay decoration on the bow these specimens can be seen as improved varieties of this type. ${ }^{138}$ The type occurred in the first half of the $6^{\text {th }}$ century and was used until the end of the $6^{\text {th }}$ century. ${ }^{139}$ Certain parts of the brooches from Jutas ${ }^{140}$ as well as the damages and repairs indicative of long-term use ${ }^{141}$ imply a later dating. The pair of brooches was probably in use during the second half of the $6^{\text {th }}$ century and buried at the end of the $6^{\text {th }}$ century.

The one-sided bone comb found in grave 196 attracted far less attention than the brooches, although the two stylized animal heads decorating its end could prove vital regarding the dating of the grave, as N. Fettich identified them as elements of animal style II. ${ }^{142}$ One-sided bone combs are known from both Langobard and Avar Period graves. Aside from an unprovenanced find from Jutas ${ }^{143}$ one such piece, decorated with stylized animal heads, came to light only from grave 42 at Tamási ${ }^{144}$ and grave 55 at Kiszombor. ${ }^{145}$ The latter find can not be dated accurately

${ }^{131}$ According to I. Bóna there is no connection between grave 196 and the rest of the cemetery. He thus dated the grave to before 568: BóNA 1956, 194. J. Werner - based on I. Bóna's observations - dated the grave between 550 and 568 with the help of the brooches: WERNER 1962, 45-48. N. Fettich however, saw the connection between grave 196 and the cemetery verified. According to him the grave fits perfectly into the structure of the cemetery, so he dated this burial to the early Avar Period. N. Fettich confuted I. Bóna's observation, that the grave is on the edge of the cemetery tampered by a gully. It came from a misinterpretation of the border of the gravel quarry drawn on the cemetery map: FETTICH 1964, 84-85.

132 BÓNA 1993, 71.

${ }^{133}$ BÓNA 1956, 211 and BÓNA 1993, 128. J. Werner reckons with the co-occurrence with the Varpalota grave 19 type not long before 568: WERNER 1962, 76.

134 The type is widely spread in Pannonia both north and south of Lake Balaton. The brooches from grave 29 at Kajdacs, grave 10 at Tamási, graves 21 and 31 at Vörs belong to the south Pannonian phase. The later dating is being confirmed by the fact that - unlike the Schwechat-Pallersdorf type - this form is known from several excavations in Italy as well (Cividale, Aquileia, graves 10 and 148 at Nocera Umbra): BIERBRAUER 1993, 129.

135 Zeitstufe 1 and 2. From the Langobard conquest till 610: BIERBRAUER 2008, 124.

${ }^{136}$ Known from graves 173 and 551 at Schretzheim, dated to the $3^{\text {rd }}$ phase $(565-590 / 600)$ of the cemetery: Косн 1977, 22-24 and 38, Taf. 143. Susanne Brather-Walter dated the appearance of the type later, to around 570, which can be explained by regional differences: BRATHER-WALTER 2009, 73.
${ }^{137} \mathrm{~J}$. Tejral dated the type in the Middle Danube region from 540 onwards as Mitteldonauländische Phäse 5-6 (540-600) TeJRAL 2005, 188. Based on Tejral's chronogy Tina Milavec dated the pieces of this type found in Slovenia to the second third of the $6^{\text {th }}$ century as well. MiLAVEC 2007, 348-350.

138 WeRnER 1962, 70 and BIERBRAUER 1993, 126. Eszter Horváth considered the brooch of uniquely high quality from a technological point of view, and regarded it a late masterpiece of local goldsmithry in line with the tradition of polychrome animal style: HORVÁTH 2012b, 214.

${ }^{139}$ KoCH 1998, 130. J. Werner dated the brooch to between 550 and 568: WERNER 1962, 45.

${ }^{140}$ The parallel to the animal head ending of the brooch is known from grave 84 at Szentes-Nagyhegy, dated to between 568 and 600 by D. Csallány: CsAlláNy 1961, 59-64 and 331. The animal head was decorated with two additional bird heads on the sides. Its closest parallel is known from grave 10 at Nocera Umbra: RuPP 2005, Taf. 20. Although implemented differently, the same solution can be found on several other brooches from Nocera Umbra (grave 68 and 158) and Castel Trosino (grave I): RuPP 2005, 84 and Taf. 160.; PAROLI-RICCI 2007, 14 and tav. 205.

${ }^{141}$ N. Fettich discusses the ways of repairs and the abrasion of different parts in great detail. Unfortunately the iron bow parts of the brooches - which were contemporary repaired - were lost during World War II. FetTICH 1964, 85-86.

${ }^{142}$ FetTich 1964, 85.

${ }^{143}$ There is an other comb from the area as well with no further stratigraphic information: FETTICH 1964, 87, 91.

144 BÓnA-B. Horváth 2009, Taf. 74.

${ }^{145}$ CSAllány 1961, 175 and Taf. CXXIV. 
without the detailed analysis of the cemetery. ${ }^{146}$ Several parallels were found in Italy: grave 122 at Castel Trosino ${ }^{147}$ as well as graves 67, 85 and 86 at Nocera Umbra. ${ }^{148}$ The specimens from grave 122 at Castel Trosino and grave 67 at Nocera Umbra are of the same type as the comb from Jutas. They are decorated with dot-in-circle ornaments and the animal head is carved in detail, with the mouth being clearly visible. The comb found in grave 4 at Acqui Terme - a cemetery used between the middle of the $6^{\text {th }}$ and the beginning of the $7^{\text {th }}$ century - was decorated the same way, the eyes on the animal heads were marked with dot-in-circles. ${ }^{149}$ The animal heads of the comb from grave 86 at Nocera Umbra - dated to between 572 and 590 by V. Bierbrauer ${ }^{150}$ - are no more than stylized forms lacking any detail.

A $14.5 \mathrm{~cm}$ long silver pin was found on the chest, near to the $S$-brooch in grave 196. There are 22 pins known from Langobard Period cemeteries in Pannonia. Except the axe-shaped pin found in Tamási, ${ }^{151}$ these were placed in the graves as part of the female attire. The pin from Jutas is the only piece that can be interpreted as a dress pin on the basis of its location; the others were found mostly next to the skull (above or right side of the skull, near the nape) and thus interpreted as hair pins. ${ }^{152}$ The pins from grave 56 at Szentendre ${ }^{153}$ and grave 21 at Szólád ${ }^{154}$ were connected to the hanging straps of the belt. Their role therefore cannot be identified. A pin was found between the right arm and thigh of a woman in grave 165 at Jutas, ${ }^{155}$ that may possibly have fastened clothing like the pin found in grave $196 .{ }^{156}$ In light of both its shape (simple pin ending in a loop) and decoration (fractionally decorated with bundles of parallel lines), the pin recovered from grave 196 belongs to the most common type of pins known from the Langobard Period of Pannonia. Its direct parallels are known from grave 25 at Gyirmót ${ }^{157}$ and grave 5 at Tamási. ${ }^{158}$ Other similar pieces were found in grave 2 at Kajdacs-Homokbánya, ${ }^{159}$ grave 56 at Szentendre, ${ }^{160}$ grave 21 at Szólád ${ }^{161}$ and grave 17 at Vörs. ${ }^{162}$ Another specimen is known from ther territory of the Czech Republic, found in grave 95 at the cemetery of Luzice. ${ }^{163}$ Pins from grave 18 at Kajdacs, ${ }^{164}$ grave 2 at Mohács ${ }^{165}$ and grave 1 at Várpalota ${ }^{166}$ were decorated the same way.

This pin type (Nadel mit Öhr) is well known in the western Merovingian world, where it was used from the beginning of the $6^{\text {th }}$ to the $7^{\text {th }}$ century. ${ }^{167}$ Close parallels to the pin from grave 196 at Jutas came to light from Italy. They are not only similar in shape but in terms of decoration as well. ${ }^{168}$ The occurrence of this pin type in Pannonia is dated to the second phase of the Langobard Period. Most such finds originate from south Pannonia, and the accompanying grave goods of the few north Pannonian examples (grave 56, Szentendre) indicate a later dating as well.

Independently of its chronological position, Hungarian research has enlisted grave 196 from the cemetery of Jutas as a Langobard burial. This interpretation is based on the Germanic/Langobard character of its grave goods as well as the burial rite. It is important to note, however, that the female dress reconstructed in grave 196 is unique in $6^{\text {th }}$ century Pannonia. As shown in the first publication of the grave, the bow brooches were located on the shoulders ${ }^{169}$ and not between the legs or on the pelvis as was common during this period. Dress pins in the chest area were not in use during the Langobard Period in Pannonia. They are found, however, in the almost contemporaneous graves of the Keszthely culture and in the early Avar Period as well, although these tend to be different types, usually stylus pins. The best parallel for wearing a pin and a small brooch on the chest together is the find recovered from the well known and often discussed Arnegunde burial. ${ }^{170}$

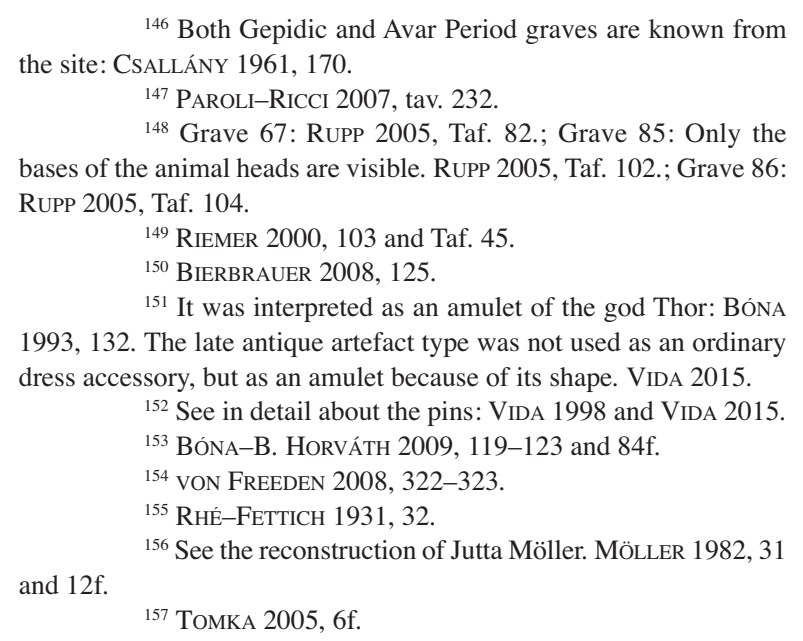

158 BónA-B. Horváth 2009, Taf. 59.

${ }^{159}$ BÓnA-B. HoRváth 2009, Taf. 20.

${ }^{160}$ BÓNA-B. HoRVÁth 2009, Taf. 50.

161 VON FREEDEN 2008, 322-323.

${ }^{162}$ SÁGi 1963, $22 \mathrm{f}$.

163 TeJRAL 2011, Taf. 73.

164 BónA-B. HoRváth 2009, Taf. 22.

${ }^{165}$ KISS-NEMESKÉRI 1964, 8f.

${ }^{166}$ BóNA 1956, Taf. XXVII.

${ }^{167}$ LOSERT 2003, 245 and 53f. The identical pin from grave 766 of Altenerding was found connected to the hanging strap like in grave 56 of Szentendre and grave 21 of Szólád. SAGE 1984, 205 and Taf. 102.

${ }^{168}$ Silver with gold decoration: Romans d'Isonzo grave 79 (RIEMER 2000, Taf. 19); Civezzano (CAMPI 1909, 120); Testona (voN Hessen 1971, Taf. 13). See several silver and bronze pieces from Nocera Umbra and Castel Trosino. In detail: RIEMER 2000, 104.

${ }^{169}$ RHÉ-FETTICH 1931, 35-36. Grave plan is not available.

${ }^{170}$ FLEURY-France-LenORD 1998. 
According to the published cemetery plan, grave 196 is surrounded by graves and it also fits within a row of graves. It is evident that the community who used this cemetery knew its place and adjusted to it, either because it is contemporaneous with the early Avar Period graves or because even if it is earlier it was somehow marked visibly above the ground. The burials form an irregular row with graves 99, 234, 167, 155, 107 and 109. Parallel to this series of burials there is an even more regular, complete row of graves (including graves 168, 169, 243, 147, 164, $165,172,174,175$ and 176). I. Bóna's observation, that grave 196 is located on the edge of the cemetery tampered by a gully was confuted by N. Fettich. ${ }^{171}$ The grave is located in the middle of the eastern part of the cemetery and could be considered one of the central burials. It is associated with the cemetery not only by its location, but by its grave goods as well: the closest parallel of the bone comb found here originates from the area of the cemetery as well.

\section{2. The cemetery of Bóly-Szeibert-puszta}

A pair of bow brooches decorated with a spiral motif and animal style, ending in an animal head was found in grave 30 at the cemetery of Bóly. ${ }^{172}$ They can be classified as type Várpalota 19-Testona. ${ }^{173}$ The closest parallels originate from Italy dated to the end of the $6^{\text {th }}$ to beginning of the $7^{\text {th }}$ century. A bow brooch decorated with splayed animal heads on its body and with nine knobs on its head came to light from grave 97 at Romans d'Isonzo ${ }^{174}$ and several brooches of this type are known from Nocera Umbra ${ }^{175}$ and Castel Trosino. ${ }^{176}$ However, the interpretation of the pair of bow brooches from Bóly is ambiguous. These brooches were found on the chest and the underbelly. The specimen in the chest area was placed upside down. The irregular location of the two brooches can be interpreted as the result of the burial rite. As is known from numerous sites in Langobard Pannonia, during the rite the hanging strap was unintentionally tucked up. ${ }^{177}$ In light of the grave goods and its location, this burial fits in perfectly within the earlier part of the cemetery, dated to the end of the $6^{\text {th }}$ or the beginning of the $7^{\text {th }}$ century. ${ }^{178}$ (Figs 5-6)

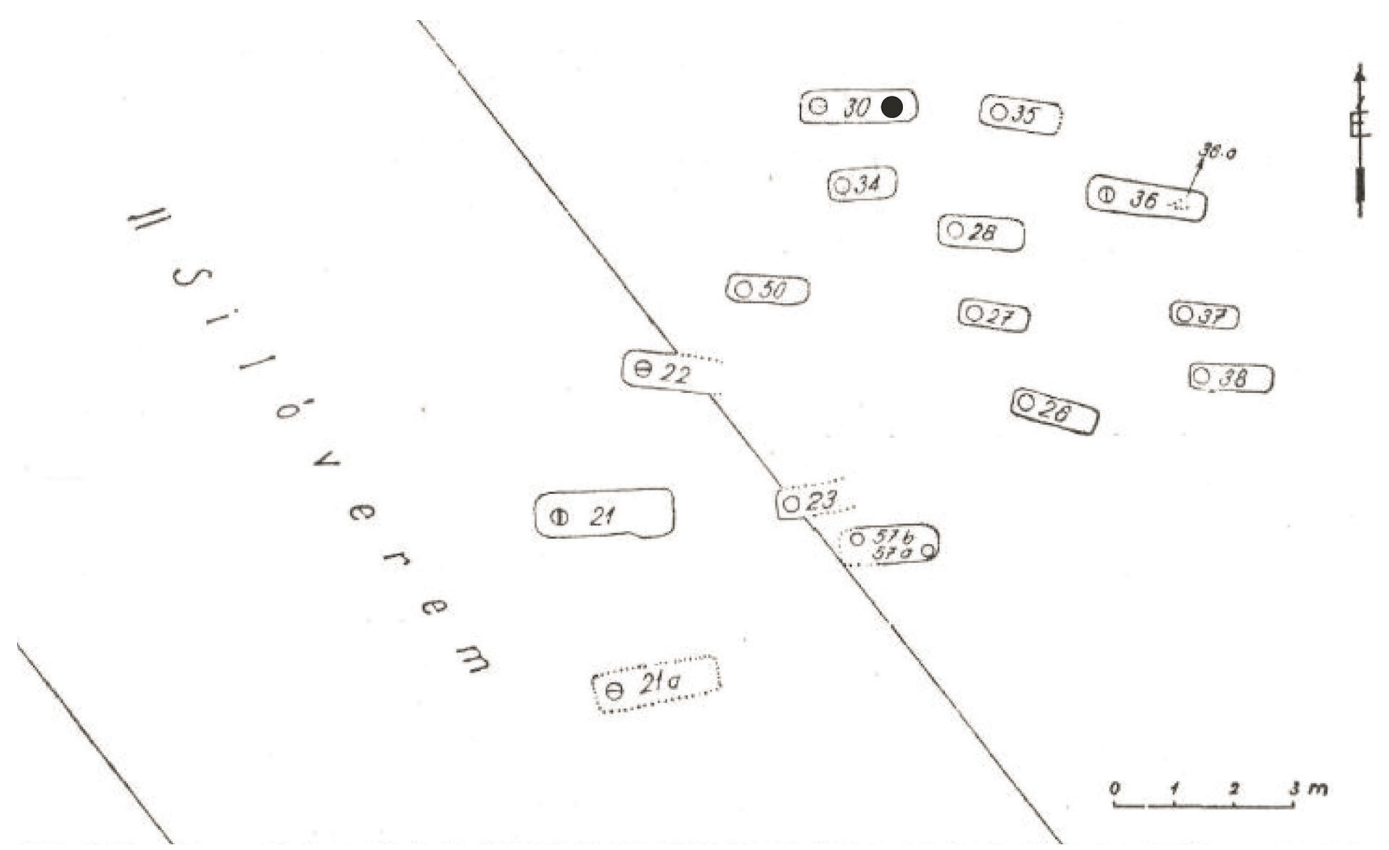

Fig. 5. Bóly grave group B with the grave 30 (after PAPP 1962)

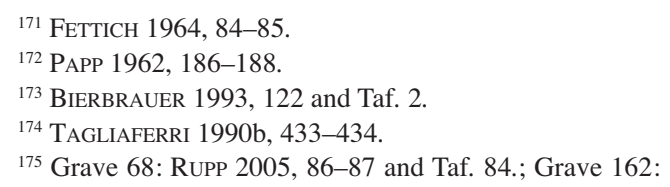

$$
\begin{aligned}
& { }^{176} \text { Grave I: PAROLI-RICCI 2005, 24-27 and tav. } 14 \text {. } \\
& { }^{177} \text { According to a different interpretation the two brooches } \\
& \text { fastened to the upper clothing on the chest and slipped down from } \\
& \text { there: VIDA } 2015 \text {. } \\
& { }^{178} \text { PÁSZTOR 1990, 131-132. }
\end{aligned}
$$

RuPP 2005, 178-179 and Taf. 162 

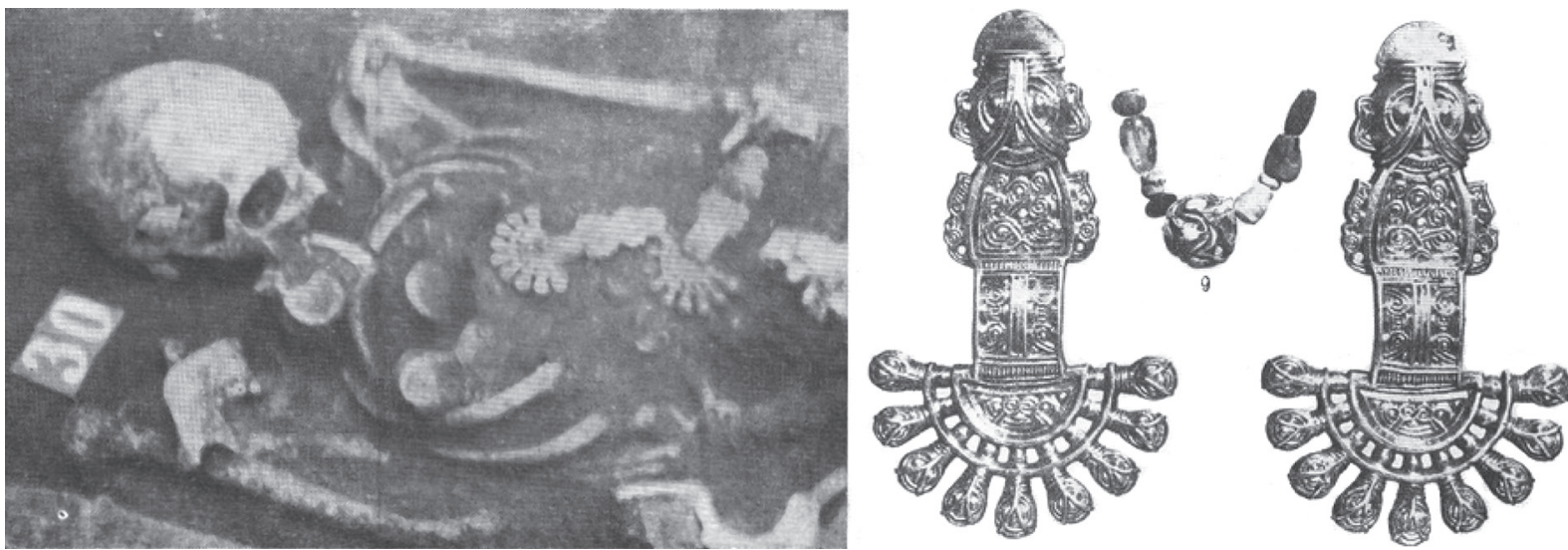

Fig. 6. Bóly grave 30 (after PAPP 1962)

\section{3. The cemetery of Gyönk-Vásártér utca ${ }^{179}$}

Langobard and Avar Period graves were not spatially separated in the cemetery of Gyönk. ${ }^{180}$ Without the detailed chronological analysis of the cemetery the connection between the Langobard and Avar Period graves can not be precisely interpreted. However, some gross characteristics are discernible.

The connection between the two parts of the cemetery or cemeteries can be observed through several superpositions. Grave 26 containing only human remains, cuts grave 32 dated to the Langobard Period. ${ }^{181}$ Therefore the former possibly belongs to the Avar Period. Although not datable on a stylistic basis, grave 19 adheres tightly to the deeper grave 20 showing the same orientation. However, superpositions can be observed between Avar Period graves as well: grave 3 was dug upon grave 1 which contained melon seed-shaped beads and grave 3 that revealed a cast, openwork bronze strap-end. ${ }^{182}$ The cemetery was in use for a very long time. It is thus possible that the Langobard Period graves fit within the texture of the cemetery, and the graves cutting into them do not necessarily date to the early Avar Period.

Graves interpreted as representing the Langobard Period were identified on the basis of a bow brooch of unknown stratigraphic position decorated with animal style I motifs ("grave 1" by I. Bóna ${ }^{183}$ ) and pottery with stamped decoration from graves 2 and 5. These types are dated to the middle and second half of the $6^{\text {th }}$ century. The Avar Period section of the cemetery was opened in the last quarter of the $6^{\text {th }}$ century. ${ }^{184}$ Therefore no major chronological hiatus can be assumed between the two parts. Grave 38 marked by four postholes is also interesting, as this structure is more of local, than eastern origin. ${ }^{185}$ (Fig. 7)

\section{4. The cemeteries around Keszthely in light of population continuity}

The continuity of populations in the region of Keszthely during the $5-8^{\text {th }}$ centuries (the so-called Keszthely culture) has a far-reaching research history. ${ }^{186}$ For a long time the dominant theory claimed that there is no continuity between the late Antique population of the $5^{\text {th }}$ century and the cemeteries opened in the second half of the $6^{\text {th }}$ century. It was presumed that a foreign population was responsible for the emergence of the Keszthely culture after $568 .{ }^{187}$

${ }^{179}$ I would like to thank János Ódor at the Wosinsky Mór County Museum (Szekszárd) for providing access to the material of the cemetery for the purpose of this analysis.

${ }^{180}$ The cemetery is yet to be published. Partial grave descriptions are known: RosNER 1970, 1972, 1975. The graves interpreted by I. Bóna as Langobard were published: BóNA-B. HORVÁTH 2009, 26-30 and Taf. 2-3

181 BÓNA-B. HORVÁTH 2009, 29.

${ }^{182}$ RosNer 1970, 41-43 and Taf. 2.
183 BÓnA-B. HoRvÁth 2009, 28.

${ }^{184}$ Rosner 1970, 77. Grave 38: RosNER 1970, Taf. 5-6.

${ }^{185}$ Graves 312, 336, 344 showed the same structure.

${ }^{186}$ In detail see: BÁLINT 1993, 225-228; BIERBRAUER 2004, especially footnote 1 . Synthesis of the question: VIDA 2011, 397-401.

${ }^{187}$ Without attempting to be comprehensive: ALFÖLDI 1926 , 30; BóNA 1970, 257; BÓNA 1971, 294-297; STRAUB 1999b, 183-184. László Barkóczi explains the occurrence of this community with newcomers as well, but dates it to before 568: BARKócZI 1971, 187. 


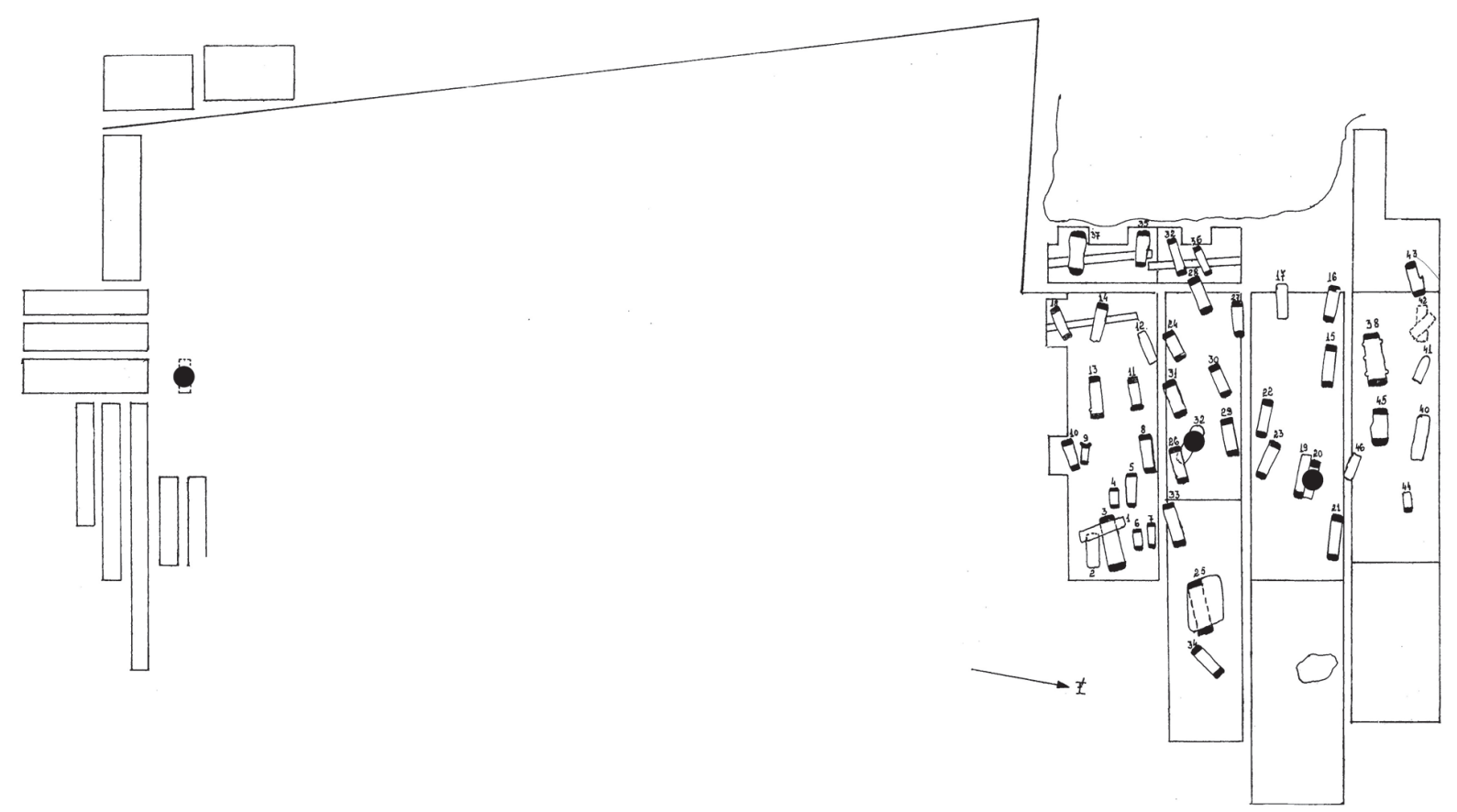

Fig. 7. Part of the cemetery of Gyönk-Vásártér utca (after RosNER 1970) - the graves identified as Langobards by I. Bóna are marked. Graves 51 and 64 are further north

At the same time a pro continuity theory existed as well. ${ }^{188}$ It has increasingly been voiced during the last decades and approached the problem not on historical grounds but using archaeological methodology. ${ }^{189}$ The Keszthely culture is not only a chronological concept. It is intimately interwoven with the highly debated problems of ethnic interpretation of archaeological material. ${ }^{190}$ In this case this concerns the late Antique, Romanised population, but this topic is beyond the focus of the current paper.

Several cemeteries in the Keszthely-Fenékpuszta area seem to have indicated that they had been founded before 568. R. Müller dated some parts of the cemetery at the southern wall of the Keszthely-Fenékpuszta fort to the first half or middle of the $6^{\text {th }}$ century, although the lack of grave goods and the character of the material made precise typochronological analyses impossible. ${ }^{191} \mathrm{By}$ the detailed evaluation of the cemetery located next to the Horreum within the fortress walls, Tivadar Vida defined an earlier phase starting as early as the middle of the $6^{\text {th }}$ century. ${ }^{192}$ This coincides with typochronological observations by V. Bierbrauer. ${ }^{193}$ The artefacts releated to this earlier phase show close connection with $5-6^{\text {th }}$ century material culture in the Mediterranean. ${ }^{194}$

Some kind of connection between the population of Langobard Period Pannonia and the community of Keszthely-Fenékpuszta is shown by the presence of S-brooches in the Horreum cemetery (graves 11, 17, 32), even if accompanying grave goods indicate that these people were buried probably during the last quarter of the $6^{\text {th }}$ century. ${ }^{195}$ The Langobard Period cemetery of Vörs located only $4 \mathrm{~km}$ away offer evidence that the Langobards were aware of the strategic importance of the location as well. ${ }^{196}$ Technological analysis by E. Horváth has demonstrated that the paragraph brooch from grave 32 at Vörs ${ }^{197}$ and the S-brooch found in grave 17 of the Horreum cemetery were made by the same goldsmith workshop. ${ }^{198}$

${ }^{188}$ Considering continuity: BARKÓCZI 1971, 190; MÜLLER 1992, 278; MÜller 2002, 93; BierbRAUER 2004.

${ }^{189}$ BIERBRAUER 2004, 68-75; VIDA 2011, 397.

${ }^{190}$ See footnote 34 .

${ }^{191}$ MÜLLER 2010, 243.

192 MÜlLer 2010, 243.

193 BIERBRAUER 2004, 51-72.

${ }^{194}$ VIDA 2011, 413 and BIERBRAUER 2004, 68-69.
${ }^{195}$ VIDA 2011, 411; on the basis of the bead finds: PÁsZTOR 2011, 243.

196 The cemetery was published by K. Sági in two parts. SÁGI 1960 and 1963. The cemetery is located at the end of the road leading through Lake Balaton: SÁGI 1960, 52 and Fig. 1.

${ }^{197}$ SÁGi 1991, 132-135.

${ }^{198}$ HoRVÁth 2012a, 225. 
The ten burials excavated at Keszthely-Fenéki street are of crucial significance in understanding the connection between Langobard Period Pannonia and cemeteries in the Keszthely region. ${ }^{199}$ Károly Sági interpreted the cemetery using the evidence of grave goods and burial customs as Langobard. With the exception of graves 7 and 8 he dated it accordingly: between 530 and 568. He tied the two exceptional graves to individuals of Germanic origin from the early Avar Period. ${ }^{200}$

The gold pendants decorated with garnet inlay found in grave 2 at Keszthely-Fenéki street raise complex questions: does their decoration belong to animal style I or II? Attribution to animal style II means that this style occurred in Pannonia before 568. Alternatively, the pendants should be dated to after $568 ?^{201}$ Based on their technological details and their parallels the pendants could be dated to the last third of the $6^{\text {th }}$ century. A pendant with gemstone inlay came to light from the already discussed cemetery of Bratislava-Rusovce. ${ }^{202}$ Similarly to the specimens found in grave 9 at Fertőszentmiklós-Szereti dülő, ${ }^{203}$ it is more simply decorated and probably earlier than the pendants from Keszthely. Researchers paid less attention to the other grave goods found in the same burial, although they reveal important relationships and connections. The rectangular gold sheets ornamented using punched decoration are known as parts of a hanging strap of Merovingian type. These are from several Langobard Period cemeteries from Pannonia, ${ }^{204}$ including the afore-mentioned cemetery of Vörs. ${ }^{205}$ It is therefore likely (given the signs of contemporaneous robbing) that the straps were used in the same way in grave 2 at Keszthely-Fenéki street as well. These punched strap mounts belong to the latest time horizon of Langobard Period Pannonia, occurring during the middle of the $6^{\text {th }}$ century. They were used in Italy as well until the end of the same century. ${ }^{206}$ The punched shield-shaped belt mount indicates a similar dating. ${ }^{207}$ On the basis of grave goods the earliest date for grave 2 can be estimated as the second half of the $6^{\text {th }}$ century. It is more likely, however, that - similarly to the individuals in graves 7 and 8 - this person was buried at the end of the $6^{\text {th }}$ century. It may also be presumed that graves of the cemetery lacking in datable finds were also contemporaneous with these burials.

The material of the cemetery from Keszthely-Fenéki street shows a tight connection with cemeteries in Langobard Period Pannonia. Certain elements however, (such as the pendants from grave 2, the damascened belt from grave 7 and the silver belt buckle and strap-end from grave 8) date the cemetery indisputably to the early Avar Period. Seen as a whole, the cemetery shows the closest relation to the earliest cemeteries of Langobard Period Italy, dated to the last third of the $6^{\text {th }}$ century. In those cemeteries parallels to the pendants, the damascened belt, ${ }^{208}$ the silver belt buckle ${ }^{209}$ and the Martinovka type strap-end ${ }^{210}$ can all be found. P. Straub explained this similarity to cemeteries in Italy with Langobard communities resettled by the Avars after the raids in Friuli at the beginning of the $7^{\text {th }}$ century. ${ }^{211}$ However, the connection already exists from the last third of the $6^{\text {th }}$ century. ${ }^{212}$ The occurrence of new artefact types and Mediterrenean influence can be explained intensifying, two-way connections ${ }^{213}$ that can be best observed between the cemeteries of Cividale del Friuli and Keszthely. ${ }^{214}$ These are the closest both geographically and chronologically, as a consequence of the Langobard conquest of Italy. Independently of ethnicity, flourishing trade connections could be a probable explanation for the outstanding wealth of the Keszthely culture.

${ }^{199}$ On a presumable Germanic population around Keszthely: BÓNA 1971, 294-301; MÜLLER 1992, 251-259; STRAUB 1999a and STRAUB 1999b; Critical synthesis of the research: HEINRICH-TAMÁSKA 2004.

${ }^{200}$ SÁGI 1991, 132-135

${ }^{201}$ Detailed stylistic and technological analysis of the pendants: SÁGI 1991, 128-130; HEINRICH-TAMÁSKA 2004, 166-167; HoRVÁTH 2012a, 220-221.

${ }^{202}$ Grave 53: SchmidTOVÁ-RUTTKAY2007, 346-347.

${ }^{203} \mathrm{P}$. Tomka dated these to the middle third of the $6^{\text {th }}$ century: TOMKA 1980, 11-16 and 20-23.

${ }^{204}$ Hegykő grave 18, Kápolnásnyék grave 2, Mohács grave 2, Szentendre grave 29 and 56, Szólád grave 25.

${ }^{205}$ Vörs grave 26: SÁGI 1963, 54 and 56-57.

${ }^{206}$ Cividale-Gallo grave 1 and 5: TAGLIAFERRI 1990b, 397 and 393.

${ }^{207}$ About the dating of shield-shaped belt mounts in detail: KonCZ 2014, 79-80.

${ }^{208}$ Damascened belt mounts are already widespread in north Italy in this period. The belt mounts from Keszthely-Fenéki street grave 7 is closest to the Civezzano type: GIOSTRA 2000, 39-52.
${ }^{209}$ See in detail about the belt buckle from Gyirmót!

${ }^{210}$ Cividale-Cella: TAgliaferri 1990b, 384. CividaleGallo grave A: TAgLiAfERri 1900b, 385. Cividale-Santo Stefano in Pertica grave 2: TAgLiaferri 1990b, 409. Cividale-San Mauro grave 44: Ahumada Silva 2010, tav. 58.

211 About the connection with Italian cemeteries: BóNA 1962, 62-64. He interpreted the brooches from graves 11 and 17 as import products from the Langobard Italy: BóNA 1993, 39. P. Straup considers the population of the Keszthely-culture constitutes of the prisoners taken during the Avar campaign in Italy in 610-11: STRAUB 1999a, 205-206; STRAUB 1999b, 182-184.

212 The Martinovka type strap-ends belong to the material culture of the first generation (572-590) of Langobards in Italy. BIERBRAUER 2008, 125.

${ }^{213}$ There is no one-way migration. BURMEISTER 2000, 544 549. Any kind of return migration means a two-way connection between the regions.

${ }^{214}$ STRAUB 1999a, 206. 


\section{THE ROLE OF LANGOBARD PERIOD POPULATIONS DURING THE EARLY AVAR PERIOD}

A segment of early Avar Period material culture has long been considered Germanic. Certain artefact types (spatha, shield, stamped pottery etc.) are attributed to the presence of different Germanic communities in Pannonia during the early Avar Period. ${ }^{215}$ Although the ethnic interpretation of artefacts (Gepids, Franks, Alamanns were all thrown into the mix) is debated, several authors pointed out the connection between the material culture of the early Avar Period and the western Merovingian world on the one hand, and with the cemeteries of the first half, middle of the $6^{\text {th }}$ century on the other. This connection can be grasped not only in sole artefacts, but in burial customs and in the female dress as a whole as well. ${ }^{216}$ As in the first half of the $6^{\text {th }}$ century we can see parallel developments in the western Merovingain world and in Pannonia, easily observable in both male and female clothing. The fashion in Pannonia changes at the same pace as in Western Europe. ${ }^{217}$ This is suggestive of strong ties that were not disrupted in 568, but remained continuous until the middle of the $7^{\text {th }}$ century. ${ }^{218}$ This continuity may be explained by the survival of the local population into the early Avar Period.

In the first phase of the early Avar Period, the cemeteries of Szekszárd-Bogyiszlói street and KölkedFeketekapu revealed burials in which Germanic characteristics could be distinguished. In the middle of the cemetery of Szekszárd-Bogyiszlói street a loose group of graves may be observed that, on the basis of the sword belt mounts recovered ${ }^{219}$ can be dated to the last third of the $6^{\text {th }}$ or beginning of the $7^{\text {th }}$ century. Graves 16 and 390 found in this area are tied to the western Merovingian world through their grave goods. ${ }^{220}$ Similar loose groups of burials can be found in cemetery B at Kölked-Feketekapu. They include grave group IX, interpreted (along with grave group V) as Gepidic. It was dated to the last third of the $6^{\text {th }}$ or beginning of the $7^{\text {th }}$ century by A. Kiss in light of its mortuary customs and grave goods. ${ }^{221}$ In the earliest phases of the cemeteries at both Szekszárd and Kölked, groups of burials stood out from the overall serial arrangement of graves ${ }^{222} \mathrm{dug}$ by a community with western Merovingian connection and local tradition can be observed. The large number of abandoned Langobard Period cemeteries and newly founded Avar Period cemeteries indicate a community level realignment that went hand in hand with the change in social structures.

The distribution area of Gepidic-related artefact types delineated by A. Kiss ${ }^{223}$ in several cases does not fall within the territory of the late Gepidic Kingdom, but within Pannonia. A. Kiss explained this discrepancy with the resettlement of the Gepids under pressure by the Avars. ${ }^{224}$ Along with the Langobard victory over the Gepids in 568 the amalgamation of those two peoples may already have started. ${ }^{225}$ The displacement of the Gepids from the central areas of the newly conquered Avar territories may thus have created a combined Germanic block that could retain its material culture and partly its identity until the middle of the $7^{\text {th }}$ century.

The exceptionally wealthy female burials from cemetery B at Kölked-Feketekapu, ${ }^{226}$ grave 2 at KeszthelyFenéki street and the illustrious male burial from Keszthely-Fenékpuszta-Pusztaszentegyházi dűlö227 indicate that

${ }^{215}$ KISS 1992, 51-59. A more critical approach: BÁLINT 1993, 242-243 and VIDA 2008, 18-29. Revisit footnote 128 for further information!

216 VIDA 2008, 18-29.

${ }^{217}$ It is evident in the stylistic development of the male belt sets: VIDA 2008, 19-24. Similarly, certain parts of the female dress (such as hanging straps) are rooted in local Germanic tradition. Their continuous development offers evidence of the close connection with the western Merovingian world: VIDA 2000b, 369-371 and 375.

${ }^{218}$ From the first third of the $7^{\text {th }}$ century onwards, hanging straps in female attire developed in a different way. This is indicated by the appearance of "Byzantine-Avar" motifs: VIDA 2000b, 369.

${ }^{219}$ See details in connection with grave 34 at Szentendre.

${ }^{220}$ Gy. Rosner already recognised the connection to the graves dated to the Langobard Period. He interpreted them as burials of "Langobard warriors": ROSNER 1999, 154-155.

${ }^{221}$ Grave group IX: KISS 2001, 335-345; Grave group V: KISs 2001, 211-217.

${ }^{222}$ A similar burial group is present in the cemetery of Budakalász: VIDA 2015.
${ }^{223}$ He defined 15 characteristic artefact types: Kiss 1992,

${ }^{224}$ KISs 1992, 63-64.

${ }^{225}$ Paulus Diaconus wrote that the Gepids had left for Italy with the Langobards as well: Paulus Diaconus II/26. According to W. Pohl King Alboin needed the remaining Gepidic army for the conquest of Italy. To a certain degree this may also have fostered the assimilation of the Gepids: PoHL 2007, 221-222.

${ }^{226}$ Graves 85 and 119: KISs 2001, 29-37 and 46-61. See the detailed analysis of these burials from a social point of view in: HeINRICH-TAMÁSKA 2011, 5-10. According to her conclusions, there were different ideologies behind the wealthy male and female graves, that were connected to different peoples.

${ }^{227}$ Grave A: MüLler 2014, 28-31 and Taf. 3-4. Grave A is dated to around 600: MüLlER 2000, 355 and MüLlER 2014, 160. The character of representation in this grave shows Avar, or possibly Italian influence. The diagnostic finds include artefacts made of precious metals in a male grave. During the Langobard Period in Pannonia precious metals were reserved for female burials. Male accessories and weapons made of or decorated with silver or gold only appeared during the last third of the $6^{\text {th }}$ century. 
these were communities with hierarchical social structures. They were lead by their own personal elites who were buried in wealthy graves superior to the graves we know from the Langobard Period of Pannonia.

These richly furnished graves manifested a new demand for self-representation. The Langobard emigration affected a significant portion of the local elites, even if we reckon with elements of the population remaining in Pannonia. The political vacuum left behind generated social competition that could explain the emergence of these affluent burials. ${ }^{228}$ In the last third of the $6^{\text {th }}$ century Pannonia and its inhabitants fell under Avar authority. ${ }^{229}$ Avar rule may have amplified the demand for self-representation by the local elites, even though they were gradually integrated into Avar society. In the end of the $6^{\text {th }}$ and beginning of the $7^{\text {th }}$ century it is probably unnecessary to speak about Gepids and Langobards. With the arrival of the Avars the conflict of identity shifted toward the GermanicAvar line.

\section{CONCLUSION}

Written sources reveal that a political power shift and an excessive change of population took place in Pannonia in 568. Archaeological data suggest, however, coexsistence between communities of different origins despite the community level realignment of society (gradual abandonment of older cemeteries and the foundation of new ones). Certain cemeteries founded during the first half of the $6^{\text {th }}$ century (Szentendre, Tamási, Gyirmót) were in use until the very end of the century. Cemeteries from the early Avar Period - founded in the last third of the $6^{\text {th }}$ century - show close ties to the Langobard Period burials, as their connection networks are the same: an intensive interaction with the western Merovingian and the Mediterranean world, this connection is evident in certain artefact types (belts, weapons, brooches) and in attire as a whole as well. The exact role and impact of the Langobard Period population during the early Avar Period can not be assessed based on the few examples emphasized in this paper, as continuity is not simply a chronological, but also a sociocultural question. Research in this area of study requires the detailed typochronological analysis of archaeological materials in this region, and the re-evaluation of the cemeteries of the period. The paper presented here is just the first step in this direction.

\section{REFERENCES}

AHUMADA SILVA 2010

ARRHENIUS 1985

BÁLINT 1993

BARKÓCZY 1971

BÂRZU 2010

BENEDIX 2015

BIERBRAUER 1993

BIERBRAUER 1996

\footnotetext{
$=$ I. AhUmada SILVA: La collina di San Mauro a Cividale del Friuli. Dalla necropoli longobarda alla chisetta bassomedievale. Ricerche di archeologia altomedievale e medievale 35-36. Firenze 2010.

$=$ B. ARRHENIUS: Merovingian garnet jewellery: emergence and social implications. Stockholm 1985.

= Cs. BÁLINT: Probleme der archäologischen Forschung zur awarischen Landnahme. In: M. MüllerWille-R. Schneider (Hrsg.): Ausgewählte Probleme der europäischen Landnahme des Früh- und Hochmittelalters. Vorträge u. Forsch. 41. Sigmaringen 1993, 195-274.

= L. BARKóCZI: Das Gräberfeld von Keszthely-Fenékpuszta aus dem 6. Jahrhundert und die frühmittelalterlichen Bevölkerungsverhältnisse am Plattensee. JRGZM 18 (1971) 179-191.

= L. BÂRZU: Ein gepidisches Denkmal aus Siebenbürgen. Das Gräberfeld Nr. 3 von Bratei. Archaeologica romanica 4. Cluj-Napoca-Bistrita 2010.

$=\mathrm{J}$. BENEDIX: Gräberfelder des 6. Jahrhunderts nach Christus aus dem Tullnerfeld und Traisental (NÖ). Freundorf - Oberndorf/E. - Pottenbrunn. Masterarbeit. Wien 2015.

= V. BIERBRAUER: Landnahme der Langobarden in Italien aus archäologischer Sicht. In: M. MüllerWille-R. Schneider (Hrsg.): Ausgewählte Probleme der europäischen Landnahme des Früh- und Hochmittelalters. Vorträge u. Forsch. 41. Sigmaringen 1993, 103-172.

$=$ V. BIERBRAUER: Romanen im fränkischen Siedelgebiet. In: Die Franken, Wegbereiter Europas. Vor 1500 Jahren: König Chlodwig und seine Erben. Katalog-Handbuch. Mainz 1996, 110-120.
}

${ }^{228}$ The creation of new communities fundamentally goes hand in hand with the realignment of the connection networks. This leads to social stress. Graves of the wealthiest usually belong to the earliest phases of cemeteries as evidence of social rivalry between leading families or other social groups. HALSALL 2010, 224.
${ }^{229}$ The value of a territory for the Avars - similarly to other nomadic societies - was probably not the territory itself, but the people inhabting it: GolDEN 1982. 
BIERBRAUER 2004

BIERBRAUER 2008

BÓNA 1956

BÓNA 1963

BÓNA 1971

BÓNA 1993

BÓNA 2000

BÓNA-B. HoRvÁTH 2009

BorgOLTE 2013

BRATHER 2004

BRATHER-WALTER 2009

BROZZI 1970

BRUCE-MitFoRd 1949

CAMPI 1909

Chapman-Hamerow 1997

CSAllány 1961

DEGRASSI 1989

Dobos 2013

FEHR 2010

FETTICH 1926

FETTICH 1964

FINGERLIN 1985

FLEURY-FRANCE-LENORD 1998

GiosTRA 2000

GOLDEN 1982

HAJNAL 2013

HAKENBECK 2008

Halsall 2010
= V. BiERBRAUER: A Keszthely-kultúra és a késő római továbbélés kérdése Pannoniában (Kr. u. 5-8. század) (Die Keszthely-Kultur und die romanische Kontinuität in Westungarn). ArchÉrt 129 (2004) 67-82.

= V. BIERBRAUER: Die Langobarden in Italien aus archäologischer Sicht. In: Die Langobarden. Das Ende der Völkerwanderung. Katalog. Darmstadt 2008, 108-151.

= I. BóNA: Die Langobarden in Ungarn. ActaArchHung 7 (1956) 183-244.

= I. BóNA: Ásatás Várpalotán (Excavation in Várpalota). DissArch 5 (1963) 119-124.

= I. BÓNA: Langobarden in Ungarn (aus den Ergebnissen von 12 Forschungsjahren). AV 21-22 (19701971) 45-75.

= I. BÓNA: A langobardok története és régészeti emlékei (Die Geschichte und die archäologische Zeugnisse der Langobarden). In: I. Bóna-J. Cseh-M. Nagy-P. Tomka-Á. Tóth-I. Zimonyi (Hrsg.): Hunok - Gepidák - Langobardok. Magyar őstörténeti könyvtár 6. Szeged 1993, 102-162.

= I. BÓNA: Ein frühawarisches Gräberfeld in der Unio-Sandgrube von Várpalota. ComArchHung 2000, 123-160.

= I. BóNA-B. HoRvÁTH: Langobardische Gräberfelder in West-Ungarn. Monumenta Germanorum archaeologica Hungariae 6. Budapest 2009.

= M. BorgOLTE: Eine langobardische „Wanderlawine“ vom Jahr 568? Zur Kritik historiografischer Zeugnisse der Migrationsperiode. Zeitschrift für Geschichtswissenschaft 2013/4, 293-310.

$=\mathrm{S}$. BRATHER: Ethnische Interpretationen in der frühgeschichtlichen Archäologie. Geschichte, Grundlagen und Alternativen. RGA Ergänzungsband 42. Berlin-New York 2004.

$=$ S. BRATHER-WALTER: Schlange - Seewesen - Raubvogel? Die S-förmigen Klein-fibeln der älteren Merowingerzeit. ZfAM 37 (2009) 47-110.

= M. Brozzi: La necropoli longobarda „Gallo” in zona Pertica in Cividale del Friuli. In: Atti del Convegno di Studi Longobardi (Udine-Cividale 15-18 maggio 1969). Ed. C. Guido Mor. Udine 1970, 95-112.

$=$ R. BRUCE-MiTFORD: Ursachen und Verlauf von Wanderungen - Anregungen für die Untersuchung prähistorischer Wanderungen. Stud. Sachsenforschungen 11 (1998) 19-41.

= L. DE CAMPI: Tombe langobarde della necropoli barbarica di Civezzano. Wien 1909.

= J. Chapman-H. Hamerow (eds): Migration and Invasion in Archaeological Explanation. BAR IntSer 664. Oxford 1997.

= D. CSALlÁNY: Archäologische Denkmäler der Gepiden im Mitteldonaubecken. 454-568. ArchHung 38. Budapest 1961.

= V. Degrassi: Tomba 74. In: F. Maselli Scotti (ed.): Longobardi a Romans d'Isonzo. Itinerario attraverso le tombe altomedievali. Trieste 1989, 57-58.

= A. DoBos: Gepidák vagy avarok? Az erdélyi kora avar kori soros temetők kutatásának kérdéseiről (Gepids or Avars? Problems related to the research of the row-grave cemeteries from the Early Avar Period in Transylvania). Dolg Új sorozat 6-7 (2011-2012) 93-118.

$=$ H. FEHR: Germanen und Romanen im Merowingerreich. Frühgeschichtliche Archäologie zwischen Wissenschaft und Zeitgeschehen. RGA Ergänzungsbände 68. Berlin-New York 2010.

= N. FetTich: Az avarkori müipar Magyarországon = Das Kunstgewerbe der Awarenzeit in Ungarn. 1: Fogazási ornamentika és ötvöseszközleletek = Zahnschnittornamentik und Pressmodellfunde. ArchHung 1. Budapest 1926.

= N. FETTICH: A jutasi avarkori temetö revíziója (Revision of the Avar Age cemetery of Jutas). VMMK 2 (1964) 79-118.

$=$ G. FINGERLIN: Hüfingen, ein zentraler Ort der Baar im frühen Mittelalter. In: Der Keltenfürst von Hochdorf. Methoden und Ergebnisse der Landesarchäologie in Baden-Württemberg. Katalog zur Ausstellung in der Josef-Haubrich-Kunsthalle Köln vom 31. Januar bis 31. März 1986. Aalen 1985, 410-449.

= M. Fleury-A. FranCE-LenORD: Les trésors mérovingiens de la basilique de Saint-Denis. Woippy 1998.

= C. GIOstRA: L'arte del metallo in età longobarda. Dati e riflessioni sulle cinture ageminate. Spoleto 2000.

$=$ P. B. GoLDEN: Imperial ideology and the sources of political unity amongst the Pre-Cinggisid nomads of Westem Eurasia. Archivum Eurasiae Medii Aevi 2 (1982) 37-76.

= Zs. HAJNAL: A Kölked-feketekapui 'A' és 'B' temetők együttes értékelése (Die zusammenfassende Auswertung der Gräberfelder 'A' und 'B' von Kölked-Feketekapu). In: Thesaurus Avarorum. Régészeti tanulmányok Garam Éva tiszteletére. Ed. T. Vida. Budapest 2012, 607-644.

$=\mathrm{S}$. E. HAKENBECK: Migration in archaeology: Are we nearly there yet? Archaeological Review from Cambridge 23/2 (2008) 9-26.

$=$ G. HALSALL: Cemeteries and Society in Merovingian Gaul: Selected Studies in History and Archaeology, 1992-2009. Leiden 2010. 
HALSALL 2012

HAMEROW 2002

HEINRICH-TAMÁSKA 2004

HEINRICH-TAMÁSKA 2005

HEINRICH-TAMÁSKA 2011

HoRVÁTH 2012a

HORVÁTH 2012b

INCITTI 1997

JARNUT 1993

KISS 1992

KISS 1996

KISS 2000

KISS 2001

KISS P. 2011

KISS-NEMESKÉRI 1964

KoBYLÍNSKI 1994

Косн 1977

КосH 1990

КосH 2001

Косн A. 1998

Kocsis 2010

KoNCZ 2014

KOVRIG 1964

LEAHY-BLAND 2009

LADENBAUER-OREL 1960

LEE 1966

LOSERT 2003
= G. HALSALL: Archaeology and migration: rethinking the debate. Relicta Monografien 7 (2012) 29-40.

$=$ H. HAMEROw: Early Medieval Settlements: The Archaeology of Rural Communities in North-West Europe 400-900. Oxford 2002.

= O. HEINRICH-TAMÁSKA: Állatornamentika a Keszthely környéki 6. századi leleteken (Tierornamentik vor und nach 568 auf den Funden in der Umgebung von Keszthely). ArchÉrt 129 (2004) 165-177.

= O. HeINRICH-TAMÁsKA: Studien zu den awarenzeitlichen Tauschierarbeiten. Monograph. zur Frühgesch. und Mittelalterarch. 11. Innsbruck 2005.

= O. HeINRICH-TAMÁsKA: Frühe „Awarinnen” und späte „Germaninnen”? - Bemerkungen zur Interpretation reicher Frauengräber der Frühawarenzeit. In: Weibliche Eliten im ersten nachchristlichen Jahrtausend - Female Elites in Protohistoric Europe. Hrsg. D. Quast. RGZM - Tagungen 10. Mainz 2011, 89-110.

= E. Horváth: Cloisonné jewellery from the Langobardic Pannonia. Technological evidence of workshop practice. In: M. Kazanski-V. Ivanisević (eds): Ponto-Danubian Territory during the Great Migration Period ( $5^{\text {th }}-6^{\text {th }}$ Centuries). Belgrade October 12-13. 2009. Belgrade 2012, 207-242.

= E. HoRvÁTH: Ékkö- és üvegberakásos ötvösmunkák a Kárpát-medence hun kori és kora meroving kori leletanyagában [Gemstone and Glass Inlaid Fine Metalwork from the Carpathian Basin: the Hunnic and Early Merovingian Periods]. Unpublished doctoral thesis, ELTE Budapest 2012.

= M. INCITTI: La necropoli altomedievale della Selvicciola ad Ischia di Castro (VT) ed il territorio castrense in età longobarda. In: L'Italia centro-settentrionale in età longobarda. Atti del Convegno Ascoli Piceno 1995. Ed. L. Paroli. Firenze 1997, 213-238.

= J. JARNUT: Die Landnahme der Langobarden in Italien aus historischer Sicht. In: M. Müller-WilleR. Schneider (Hrsg.): Ausgewählte Probleme der europäischen Landnahme des Früh- und Hochmittelalters. Vorträge u. Forsch. 41. Sigmaringen 1993, 173-194.

= A. KIss: Germanen im awarenzeitlichen Karpatenbecken. In: F. Daim (Hrsg.): Awarenforschungen. Archaeologica Austriaca Monographien 1. Studien zur Archäologie der Awaren 4. Wien 1992, 35-134.

= A. KISs: Das awarenzeitlich gepidische Gräberfeld von Kölked-Feketekapu A. Monographien zur Frühgeschichte und Mittelalterarchaologie. Studien zur Archaologie der Awaren 2/5. Innsbruck 1996.

= A. KIss: Die Frage des Weiterlebens der Gepiden. ActaArch 51 (1999/2000) 359-366.

= A. KISS: Das awarenzeitliche Gräberfeld in Kölked-Feketekapu B. Monumenta Avarorum archaeologica 6. Budapest 2001

= A. Kiss P.: Die awarenzeitlichen Gepiden in Transdanubien? Gemischte Argumentationen in der Forschung bei dem Weiterleben der Gepiden. In: Church and Ethnicity in History. First year of Conference V4 doctoral candidates in Ostrava. Ed. B. Vida. Ostrava, 2011, 10-20.

= A. KISS-J. NEMESKÉRI: Das langobardische Gräberfeld von Mohács. JPMÉ 9 (1964) 95-127.

$=Z$. KobYLÍnSKI: An ethnic change or a socio-economic one? The $5^{\text {th }}$ and the $6^{\text {th }}$ centuries AD in the Polish lands. In: Archaeological Approaches to Cultural Identity. Ed. S. J Shennan. London-New York 1994, 303-312.

= U. KocH: Das Reihengräberfeld bei Schretzheim. GDV Serie A 13. Berlin 1977.

= U. Косн: Das fränkische Gräberfeld von Klepsau im Hohenlohekreis. Forschungen und Berichte zur Vor- und Frühgeschichte in Baden-Württenberg 38. Stuttgart 1990.

= U. KocH: Das alamannisch-fränkische Gräberfeld bei Pleidelsheim. Forschungen und Berichte zur Vor- und Frühgeschichte in Baden-Württemberg 60. Stuttgart 2001.

= A. KocH: Bügelfibeln der Merowingerzeit im westlichem Frankenreich. Monographien des Römisch-Germanisches Zentralmuseums, Forschungsinstitut für Vor- und Frühgeschichte 41. Mainz 1998

= L. Kocsis: A tiszagyendai régészeti ásatás (2006-2007.) leletei (Archaeological finds from the excavation (2006-2007) at Tiszagyenda). In: Örök megújulás. Az ezredforduló új szerzeményei a Magyar Nemzeti Múzeumban. Ed. L. Pallos. Budapest 2010, 17-19.

= I. KonCZ: A hegykői 6. századi temető időrendje és kapcsolatrendszere (The chronology and cultural contacts of the $6^{\text {th }}$-century cemetery at Hegykö). ArchÉrt 139 (2014) 71-98.

= I. Kovrig (rez.): Werner, J.: Die Langobarden in Pannonien. München 1962. ArchÉrt 91 (1964) $145-147$.

= K. LEAHY-R. BLAND: The Staffordshire Hoard. London 2009.

$=$ H. LAndenbauer-Orel: Linz-Zizlau. Das baierische Gräberfeld an der Traunmündung. WienMünchen 1960.

= E. LEE: A theory of migration. Demography 3/1 (1966) 47-57.

$=$ H. LOSERT: Das frühmittelalterliche Gräberfeld von Altenerding in Oberbayern und die "Ethnogenese" der Bajuwaren. 1. Berlin 2003 
LUCY 2000

MARTIN 1976

MARTIN 1990

MARTIN 1996

MARTIN 2008

Menghin 1983

MilaVec 2007

MÖLLER 1982

MuHL 1994

MÜLLER 1992

MÜLLER 2000

MÜLLER 2002

MÜLLER 2014

MÜSSEMEIER et al. 2003

NADJ 1959

Neugebauer 2005

PAPP 1962

PAROLI-RICCI 2007

PÁSZTOR 1990

PÁsZTOR 2011

Paulsen 1967

PoHL 1988

PoHL 2007

PRIEN 2005

RÁCZ 2014

RHÉ-FetTICH 1931

RICCI-LUCCERINI 2001

RIEMER 2000
$=$ S. LuCY: The Anglo-Saxon Way of Death: Burial Rites in Early England. Sutton 2000.

= M. MARTin: Das fränkische Gräberfeld von Basel-Bernerring. Basler Beiträge zur Ur- und Frühgeschichte 1. Basel 1976.

= M. MARTIN: Awarische und germanische Funde in Männergräbern von Linz-Zizlau und Környe. Ein Beitrag zur Chronologie der Awarenzeit. WMMÉ 15 (1990) 65-90.

= M. MARTIN: Tauschierte Gürtelgarnituren und-beschläge des frühen Mittelalters im Karpatenbecken und ihre Träger. In: A. Kiss: Das awarenzeitlich gepidische Gräberfeld von Kölked-Feketekapu A. Monographien zur Frühgeschichte und Mittelalterarchaologie. Studien zur Archaologie der Awaren 2/5. Innsbruck 1996, 345-362.

= M. MARTIN: Die absolute Datierung der Männergürtel im merovingischen Westen und im Awarenreich. Antaeus 29/30 (2008) 143-174.

=W. Menghin: Das Schwert im frühen Mittelalter. Wissenschaftliche Beibände zum Anzeiger des Germanischen Nationalmuseums 1. Stuttgart 1983.

$=\mathrm{T}$. Milavec: Prispevek h kronologiji S-fibul v Sloveniji (A contribution to the chronology of Sfibulae in Slovenia). AV 58 (2007) 333-355.

= J. MöLLER: Zur Funktion der Nadel in der fränkisch-alamannischen Frauentracht. JRGZM 23-24 (1976-77) [1982] 14-53.

= A. MuHL: Tauschierarbeiten der Merowingerzeit. Kunst und Technik. Bestandskataloge 2. Berlin 1994.

= R. MÜLlER: Neue archäologische Funde der Keszthely-Kultur. In: F. Daim (Hrsg.): Awarenforschungen. 1. Archaeologia Austriaca Monographien 1. Studien zur Archäologie der Awaren 4. Wien 1992, 251-307.

= R. MÜLLER: Ein germanisches Grab der Frühawarenzeit aus Keszthely-Fenékpuszta. ActaArchHung 51 (2000) 341-357.

= R. MüLLER: Die Bevölkerung von Fenékpuszta in der Frühawarenzeit. ZalaiMúz 11 (2002) 93-102.

= R. MÜLLER: Die Gräberfelder von Keszthely-Fenékpuszta, Ödenkirche-Flur. Castellum Pannonicum Pelsonense 5. Budapest-Leipzig-Keszhtely-Rahden/Westf. 2014.

= U. Müssemeier-E. Nieveler-R. Plum-H. PöpPelmann: Chronologie der merowingerzeitlichen Grabfunde vom linken Niederrhein bis zur nördlichen Eifel. Materialen zur Bodendenkmalpfelege im Rheinland 15. Köln 2003.

= S. NADJ: Die Nekropole bei Aradac aus dem frühen Mittelalter. Rad Muzeja Vojvodnje - Work of Museum of Voivodina 8 (1959) 45-102.

= J-W. Neugebauer: Langobarden im 6. Jahrhundert im unteren Traisental. Die Gräberfelder von Pottenbrunn und Oberndorf in der Ebene. In: W. Pohl-P. Erhart (Hrsg.): Die Langobarden. Herrschaft und Identität. Ergebnisse eines vom 2. bis 4. November 2001 in Wien abgehaltenen internationalen Symposiums. Öster. Akad. Wiss. Phil.-Hist. K1., Denschr. 329. Forsch. Gesch. Mittelalter 9. Wien 2005, 321-331.

= L. PAPP: A bólyi avarkori temető (Der awarenzeitliche Friedhof von Bóly). JPMÉ 7 (1962) 163-193.

= L. PAROLI-M. RiCCI: La necropoli altomedievale di Castel Trosino. 1-2. Ricerche di archeologia altomedievale e medievale 32-33. Firenze 2007.

= A. PÁszTor: A bólyi avarkori temető értékelése (Die Auswertung des Bólyer awarenzeitlichen Gräberfeldes). JPMÉ 34 (1990) 93-129.

= A. PÁszTOR: A Keszthely-Fenékpuszta horreum melletti temető gyöngyleleteiről (Perlenfunde aus dem Horreum-Gräberfeld Keszthely-Fenékpuszta). MFMÉ - Studia Achaeologica 12 (2011) 235-244.

= P. PAulsen: Alamannische Adelsgräber von Niederstotzingen. Veröffentlichungen des Staatliches Amtes für Denkmalpflege Stuttgart. Vor- und Frühgeschichte A/12. Stuttgart 1967.

= W. Pohl: Die Awaren. Ein Steppenvolk in Mitteleuropa, 567-822 n. Chr. München 1988.

=W. PoHL: Alboin und der Langobardenzug nach Italien. Aufstieg und Fall eines Barbarenkönigs, In: Sie schufen Europa. Historische Portraits von Konstantin bis Karl dem Großen. Hrsg. M. Meier. München 2007, 216-227.

$=$ R. PRIEN: Archäologie und Migration. Vergleichende Studien zur archäologischen Nachweisbarkeit von Wanderungsbewegungen. UPA 120. Bonn 2005.

= Zs. RÁCZ: Die Goldschmiedegräber der Awarenzeit. Monographien RGZM 116. Mainz 2014.

= Gy. RhÉ-N. FetTich: Jutas und Öskü. Zwei Gräberfelder aus der Völkerwanderungszeit in Ungarn. Prag 1931.

= M. RICCI-F. LuCCERINI: Oggett di abbigliamento e ornamento. In: M. S. Arena-P. Delogu-L. ParoliM. Ricci-L. Sagui-L. Vendittelli (ed.): Roma dall'antichità al medioevo. La storia, in Roma dall'antichità al medioevo. Archeologia e storia nel Museo Nazionale Romano Crypta Balbi. Milano 2001, 351-387.

= E. RIEMER: Romanische Grabfunde des 5-8. Jahrhunderts in Italien. IntArch 57. Rahden/Westf. 2000. 
ROSNER 1970

ROSNER 1999

RuPP 2005

SAGE 1984

SÁGI 1960

SÁGI 1963

SCHMIDTOVÁ-RUTTKAY 2007

SCHMIDTOVÁ-RUTTKAY 2008

SCHULZE-DÖRRLAMM 2002

SCHMIDTOVÁ et al. 2009

SIEGMUND 1998

SOMOGYI 2014

STADLER 2008

STADLER et al. 2005

STEUER 1977

STRAub 1999a

StRAub 1999b

TAGLIAFERRI 1990a

TAGLIAFERRI $1990 \mathrm{~b}$

TĂNASE 2010

TEJRAL 2005

TOMKA 1980

TOMKA 2005

TOMKA 2008
= Gy. RosNER: Újabb adatok Tolna megye avarkori történetének kutatásához [Recent data to the Avar period research of Tolna County]. BBÁMÉ 1 (1970) 40-95.

= Gy. RosnER: Das awarenzeitliche Gräberfeld in Szekszárd-Bogyiszlói Strasse. Monumenta Avarorum archaeologica 3. Budapest 1999.

= C. RupP: Das langobardische Gräberfeld von Nocera Umbra. Firenze 2005.

=W. SAGE: Das Reihengräberfeld von Altenerding in Oberbayern. Germanische Denkmäler der Völkerwanderungszeit: Serie A 14. Berlin 1984.

= K. SÁGI: A vörsi langobard temető (The Langobard cemetery of Vörs). ArchÉrt 87 (1960) 52-60.

= K. SÁGI: A vörsi langobard temetô újabb ásatási eredményei (New results of the excavation of the Langobard cemetery of Vörs). VMMK 1 (1963) 39-79.

= J. SchmidtovÁ-M. RutTKAy: Das merowingerzeitliche Gräberfeld in Bratislava-Rusovce, Lage Pieskový hon. In: Barbaren im Wandel. Beiträge zur Kultur- und Identitätsumbildung in der Völkerwanderungszeit. Hrsg. J. Tejral. Brno 2007, 339-359.

$=$ J. SchMidTOVÁ-M. RutTKAY: Das langobardische Gräberfeld von Bratislava-Rusovce. In: Kulturwandel in Mitteleuropa. Langobarden-Awaren-Slawen. Hrsg. J. Bemann. Kolloquien zur Vor- und Frühgeschichte 11. Bonn 2008, 377-398.

= M. SCHUlzE-DöRRLAMM: Byzantinische Gürtelschnallen und Gürtelbeschläge im Römisch-Germanischen Zentralmuseum. 1: Die Schnallen ohne Beschlag, mit Laschenbeschlag und mit festem Beschlag des 5. bis 7. Jahrhunderts. Kataloge Vor- und Frühgeschichtlicher Altertümer 30. Mainz 2002.

= J. SchmidtovÁ-A. ŠEFČÁKovÁ-M. Thurzo-J. BrŮŽEK-D. CASTEX-M. RutTKAY: Lombards on the Middle Danube: a new Migration Period cemetery in Bratislava-Rusovce, Slovakia. Antiquity 83. Issue 319. Cambridge 2009.

= F. SIEGMUND: Merowingerzeit am Niederrhein. Die frühmittelalterlichen Funde aus dem Regierungsbezirk Düsseldorf und dem Kreis Heinsberg. Rheinische Ausgrabungen 34. Köln 1998.

= P. Somogyi: Der gegossene Silberbeschlag mit durchbrochener Verzierung im Münzgrab von Freundorf (Tulln, NÖ, Österreich). In: A. Anders-Cs. Balogh-A. Türk (eds): Avarum solitudines. Archaeological studies to Gábor Lőrinczy on his sixties birthday. Budapest 2014, 235-242.

= P. StadleR: Maria Ponsee. In: Die Langobarden. Das Ende der Völkerwanderung. Katalog. Darmstadt 2008, 275-281.

= P. Stadler-H. Friesinger-W. Kutschera-A. Priller-P. SeIer-E. M. Wild: Ein Beitrag zur Absolutchronologie der Langobarden aufgrund von 14C-Datierungen und ein Versuch zur Datierung der Beraubung langobardischer Gräber. ArchA 872003 (2005) 265-278.

$=$ H. STEUER: Bemerkungen zur Chronologie der Merowingerzeit. Studien zur Sachsenforschung 1. Hildesheim 1977. 379-402.

= P. STRAub: A Keszthely-kultúra kronológiai és etnikai hátterének újabb alternetívája (Die neuere Alternative des chronologischen und ethnischen Hintergrundes der Keszthely-Kultur). ZalaiMúz 9 (1999) 195-224

= P. STRAUB: Újabb adalék a Keszthely-kultúra eredetéhez egy fenékpusztai sír kapcsán (Ein neuer Beitrag zum Ursprung der Keszthely-Kultur anhand eines Grabes von Fenékpuszta). ZalaiMúz 9 (1999) 181-193.

= A. TAgLIAFERri: Analisi insediativa di due ducati: Il ducato di Forum Iulii. In: I Longobardi. Milano 1990, 102-112.

= A. TAGLIAFERRI: Il ducato di Forum Iulii. In: I Longobardi. Milano 1990, 358-476

= D. TĂNASE: Einige Bemerkungen im Bezug mit der Schmiedegraben aus der Awarischen Zeit Gefunden im Felnac (Kreis Arad) (Zusammenfassung). Analele Banatului Serie noua: Arheologie-Istorie 12-13 (2005) 237-264.

$=$ J. TEJRAL: Zur Unterscheidung des vorlangobardischen und elbgermanischlangobardischen Nachlasses In: W. Pohl-P. Erhart (Hrsg.): Die Langobarden. Herrschaft und Identität. Ergebnisse eines vom 2. bis 4. November 2001 in Wien abgehaltenen internationalen Symposiums. Öster. Akad. Wiss. Phil.-Hist. K1., Denschr. 329. Forsch. Gesch. Mittelalter 9. Wien 2005, 101-175.

= P. TomkA: Das germanische Gräberfeld aus dem 6. Jh. in Fertőszentmiklós. ActaArchHung 32 (1980) 5-30.

= P. TOMKA: Langobardenforschung in Nordwestungarn. In: W. Pohl-P. Erhart (Hrsg.): Die Langobarden. Herrschaft und Identität. Ergebnisse eines vom 2. bis 4. November 2001 in Wien abgehaltenen internationalen Symposiums. Öster. Akad. Wiss. Phil.-Hist. K1., Denschr. 329. Forsch. Gesch. Mittelalter 9. Wien 2005, 247-264.

= P. ToMKA: Langobardisches Gräberfeld in Gyirmót-Homokdomb. In: Sie kamen und gingen. Langobarden und Awaren in der Kleinen Tiefebene. Exhibition catalogue: Xántus János Múzeum, Győr, 2008. október 9-2009. január 30. Győr 2008, 31-43. 
TÖRÖK 1981

VIDA 1998

VIDA 2000a

VIDA 2000b

VIDA 2008

VIDA 2011

VIDA 2015

VINSKI 1958

VON FREEDEN 2000

Von Hessen 1968

Von Hessen 1971

WERNER 1955

WERNER 1962

WERNER 1973

WICKHAM 2005

ZEISS 1934
= GY. TÖRÖK: The Csengele-Feketehalom cemetery. In: Das awarische Corpus 4. Debrecen-Budapest 1995, 208-243.

$=\mathrm{T}$. VIDA: The veil pin or dress pin. Data to the question of Avar period pin-wearing. Antaeus 24 (1997-1998) 563-574.

$=\mathrm{T}$. VIDA: Merowingische Spathagurte der Awarenzeit. ComArchHung 2000, 161-175.

$=$ T. VIDA: Ziergehänge der awarenzeitlichen Frauen im Karpatenbecken. Festschrift von István Bóna ActaArch 51 (1999/2000) 367-377.

$=\mathrm{T}$. VIDA: Conflict and coexsistence: the local population of the Carpathian Basin under Avar rule (sixth to seventh century). In: The Other Europe in the Middle Ages. Avars, Bulgars, Khazars, and Cumans. Ed. F. Curta. Leiden-Boston 2008, 13-46.

$=\mathrm{T}$. VIDA: Das Gräberfeld neben dem Horreum in der Innenbefestigung von Keszthely-Fenékpuszta. In: Keszthely-Fenékpuszta im Kontext spätantiker Kontinuitätsforschung zwischen Noricum und Moesia. Ed. O. Heinrich-Tamáska. Castellum Pannonicum Pelsonense 2. Budapest-Leipzig-Keszthely-Rahden/Westf 2011, 397-456.

= T. VIDA: A sztyeppei, a bizánci és a Meroving birodalmak között. Kulturális változások a Kárpátmedence nyugati felén a 6-7. században. Avar, germán és romanizált népesség a sztyeppei, a bizánci és a Meroving birodalmak között (Between steppe, Byzantine and Merovingian Empires. Cultural changes between the 6-7 $7^{\text {th }}$ centuries in the western part of the Carpathian Basin). Unpublished 2015.

= Z. VINSKI: O nalazima 6. i 7. stoljeca u Jugoslaviji s posebnim obzirom na arheolosku ostavstinu iz vremena prvog avarskog kaganata ( $\mathrm{Zu}$ den Funden des 6. und 7. Jahrhunderts in Jugoslawien mit besonderer Berücksichtigung der archäologischen Hinterlassenschaft aus der Zeit des ersten awarischen Khaganates). OpArch 3 (1958) 13-67.

= U. vON FREEDEN: Ausgewählte Befunde aus dem langobardenzeitlichen Gräberfeld von Szólád, Komitat Somogy, Ungarn. In: Kulturwandel in Mitteleuropa. Langobarden-Awaren-Slawen. Hrsg. J. Bemann. Kolloquien zur Vor- und Frühgeschichte 11. Bonn 2000, 399-413.

= O. VON HESSEN: I ritrovamenti barbarici nelle collezioni civiche veronesi del Museo di Castelvecchio. Verona: Museo di Castelvecchio 1968.

= O. VON HESSEN: Die langobardischen Funde aus dem Gräberfeld von Testona, Moncalieri/Piemont. Turin 1971.

= J. WERNER: Byzantinische Gürtelschnallen des 6. und 7. Jahrhunderts aus dem Sammlung Diergardt. KölnerJb 1 (1955) 36-48.

= J. Werner: Die Langobarden in Pannonien. Bayer. Akad. Wiss. Phil.-Hist. Kl. Abhandl. N. F. 55A. München 1962.

= J. Werner (Rez. zu): Peter Paulsen: Alamannische Adelsgräber von Niederstotzingen (Kreis Heidenheim). Veröff. Staatl. Amt Denkmalpflege A 12 (Stuttgart 1967). Germania 51 (1973) 278-289

= C. Wicкнам: Framing the Early Middle Ages. Europe and the Mediterranean 400-800. Oxford 2007.

= H. ZeIss: Rechteckige Beschläge vom Typ Weihmörting Grab 188. BVbl 12 (1934) 39. 